\title{
Structuring the phenomenon of procurement digitalisation: contexts, interventions and mechanisms
}

\begin{tabular}{|r|l|}
\hline Journal: & International Journal of Operations and Production Management \\
\hline Manuscript ID & IJOPM-03-2020-0150.R3 \\
\hline Manuscript Type: & Research Paper \\
\hline Keywords: & $\begin{array}{l}\text { Digtalisation, Procurement, Purchasing and supply management, Case } \\
\text { study }\end{array}$ \\
\hline \multicolumn{2}{|l}{} \\
\hline
\end{tabular}

\section{SCHOLARONE \\ Manuscripts}




\title{
Structuring the phenomenon of procurement digitalisation: contexts, interventions and mechanisms
}

\begin{abstract}
Purpose - The study develops a structure for procurement digitalisation by identifying its context drivers, technology interventions and performance-inducing mechanisms and exploring the linkages between these variables.

Methodology - The study draws on rich interview and workshop data on 48 digital intervention projects, as reflected by mental models of managers from 12 case organisations in manufacturing, retail and service sectors. Supported by an a priori structure, the study employs an abductive cross-case analysis approach.
\end{abstract}

Findings - Results suggest several categories within the elements of context, intervention and mechanism to structure procurement digitalisation and the linkages between them. Seven propositions that reflect digitalisation strategy options in procurement are developed regarding the linkages. Internal complexity dominantly drives procurement digitalisation, motivating communication support and process structuring interventions, which in turn aim at procurement coordination and control as well as process improvement. External coercive pressure and external dynamism also drive interventions for information processing and decision aiding, which appear to be linked with supply market knowledge, strategic alignment and supplier capability assessment. Therefore, an internal-external dichotomy is observed as the main thrust of procurement digitalisation.

Practical implications - The study supports decision makers in developing digitalisation strategy options for different procurement contexts. The results also raise awareness of a possible bias in existing strategies for procurement digitalisation.

Originality - A novel forward-looking approach is employed to enable the design and construction of systems that do not yet exist by focusing on the mental models of managers in a systematic way.

Keywords: Digitalisation, procurement, purchasing and supply management, case study Article classification: Research Paper

\section{Introduction}

The adoption of technologies pertaining to Industry 4.0 or digitalisation in procurement has been touted as the catalyst for revolutionising the way vital upstream supply networks are managed. This has led procurement functions to seek, discover and experiment with new technology solutions (Gualandris et al., 2018). Although digitalisation of the procurement function may be regarded as desirable, and thus imperative for forward-looking organisations (Sanders, 2016), a more critical view should consider various factors influencing the adoption of new technologies for managing supply. 
The contextual variables influencing procurement digitalisation may be divided into those of efficiency and non-efficiency orientation in nature (Sousa and Voss, 2008). Such a theoretical perspective enables a critical evaluation of the boundaries for propositions regarding universalistic adoption of various digital technology applications within procurement (cf. Busse et al., 2017), and allows for more informed practical interventions. Moreover, these factors should be linked with dependent or response variables, namely those reflecting organisational or managerial action and practice effectiveness (Sousa and Voss, 2008). While notable advances in this respect have been made, for example by Søgaard et al. (2019) and Handfield et al. (2019), the present study employs an integrated view of digital technologies and applications within a set of emergent context and response variables.

This study addresses this research gap by aiming to structure the phenomenon of procurement digitalisation in two key aspects. Firstly, it identifies driver-oriented context variables and response variables in terms of digital technology interventions and performance-inducing mechanisms (cf. Denyer et al., 2008). Secondly, by exploring the linkages between these variables, this study seeks to develop propositions for inducing further research on procurement digitalisation and providing strategy options for practical purposes. The key construct of the study - procurement digitalisation - is defined simply as the use of digital technologies, such as the Internet of Things, mobile applications, cloud computing, big data, 3D printing, social networks, human-computer interaction, artificial intelligence, autonomous robots and blockchain technology, to support or enhance procurement processes (cf. Srai and Lorentz, 2019).

In addressing the research aims, this study draws on interview and workshop data from 12 case companies. The nature of the phenomenon of interest presents an interesting challenge for this research. Much of procurement digitalisation has not yet been realised at scale, at least in its advanced forms, including predictive analytics, artificial intelligence and blockchains (Handfield et al., 2019; Gray and Prud'homme, 2019). Therefore, observing the actual states of the response variables is challenging. It follows that this study employs a forward-looking approach and seeks to enable the design and construction of the artificial, that is, systems that do not yet exist (Simon, 2019), by focusing on the mental models of managers regarding the linked context and response variables within the domain of procurement digitalisation. Defined by Gary and Wood $(2011,569)$ in the management domain as 'simplified knowledge structures or cognitive representations about how the business environment works', mental models may be regarded as predictors of future states (Morecroft, 1992) because decision makers act on the subjective cognitive structures or mental models of the environment (Daft and Weick, 1984; Porac and Thomas, 1990). Importantly, the variation in mental models explains the variation in adopted strategies and competitive success (Gary and Wood, 2011). Therefore, mental models contain information about causality and, as proxies of realised events, can be used to study the key variables of the procurement digitalisation phenomenon.

\section{Theoretical foundations for structuring procurement digitalisation}


In the quest for structuring the procurement digitalisation phenomenon, a theoretically sound a priori structure is considered an imperative. Such a theoretical foundation for this study is provided by the so-called CIMO logic (Denyer et al., 2008), which has been proposed to serve as a template for structuring problem-solving propositions in any management context. In this logic, $\mathrm{C}$ stands for a problematic context, defined as the factors pertaining to the external and internal environment, such as organisational politics and power, organisational stability, uncertainty and system interdependencies (Denyer et al., 2008). The relevant context here is understood to drive procurement digitalisation. Furthermore, regarding the response variables, I stands for a key component of the logic, specifically, the intervention through which the problematic context or driver should be addressed or the means 'managers have at their disposal to influence behavior' (Denyer et al., 2008, 397). M is 'the mechanism that in a certain context is triggered by the intervention', perhaps essentially representing the new state or capability that results from managerial intervention and through which the final element, namely the outcome $(\mathrm{O})$, takes place or is brought about. As the current study relies on the mental models of managers about a phenomenon in an emerging state, the performance effects of which are thus difficult to estimate, the final outcome response variable is considered to be out of the scope of the study. Next, the remaining elements of the a priori foundational logic (CIM) are discussed in the context of procurement technology adoption.

\subsection{Contextual variables driving procurement technology adoption}

Several theoretical lenses may be considered to fully understand the variety of context variables for procurement digitalisation, or more broadly, procurement technology adoption. We select theories which (1) specifically address the interaction of the firm with its context and (2) are discussed in supply chain and procurement or e-procurement literature (Spina et al., 2016). We end up selecting theories that allow the context to vary and are useful in explaining intervention adoption in different contexts, including contingency theory (Sousa and Voss, 2008; as applied to procurement: Bals et al., 2018), strategic choice theory (Child, 1972; as applied to procurement: Shook et al., 2009) and institutional theory (DiMaggio and Powell, 1983; as applied to procurement: Zsidisin et al., 2005). With focus on theories related to the interaction of context and firm, such theoretical frameworks as the resource-based view (e.g. Barney 1991), transaction cost economics (e.g. Williamson 1981), and the knowledgebased view (Kogut and Zander, 1992 Nonaka, 1994), are not selected as theoretical lenses.

Management practices and technologies, or more generally, interventions, may be undertaken or adopted due to the influence of efficiency factors (i.e. based on a rational analysis of the interventions' optimal fit with the problematic context) even in a rather deterministic manner. This efficiency perspective is deeply rooted in the contingency theory of organisations (Donaldson, 2001; Donaldson, 1987). Therefore, the approach may also be demarcated as defining associations between the context and response variables (cf. Luthans and Stewart, 1977). Context may be divided into internal and external environment (Duncan, 1972), as is often the case in contingency-theory-oriented studies (Luthans and Stewart, 1977). In the procurement context, Ellram et al. (2002) point out early on the contingent nature of purchasing best practices; for example, the efficacy of purchasing organisation structure (Bals 
et al., 2018), lean purchasing (Azadegan et al., 2013) and management of buyer-supplier relationships (Saccani and Perona, 2007) was subsequently shown to depend on external and internal contingencies, such as environmental complexity and dynamism (Duncan, 1972).

However, the assumptions underlying the design for efficiency-oriented mental models may be relaxed, as interventions in procurement may also be driven by a variety of non-efficiency variables, possibly giving rise to panaceas (Sousa and Voss, 2008). Such cases may be appropriately covered by using institutional theory (DiMaggio and Powell, 1983). In contrast to the contingency theoretical approach for context-determined practices, institutional theory focuses on understanding the production of external legitimacy and support through three isomorphic mechanisms: (1) coercive pressure, which stems from political influence and the need for legitimacy; (2) mimetic pressure, which results from standard responses to uncertainty; and (3) normative pressure, which is associated with professionalisation (DiMaggio and Powell, 1983, 150). In the general supply management context, Zsidisin et al. (2005) propose that isomorphic pressures result in similar supply risk management practices, and Zhu et al. (2013) show similar tendencies in terms of green supply practice adoption.

With this recognition of the role of both efficiency and non-efficiency contextual variables in driving the uptake of procurement practices, the contexts and drivers of e-procurement adoption are next observed. This is done to establish a foundation for making educated empirical observations regarding the phenomenon of procurement digitalisation and evaluating the adequacy of the selected theoretical perspectives. Relying on the eprocurement literature is necessary due to the paucity of relevant procurement digitalisation literature, as only Søgaard et al. (2019) imply the contingent nature of adoption of digital technologies in procurement. By contrast, Sanders (2016) adopts a rather universalistic perspective regarding procurement analytics. Kosmol et al. (2019) emphasise the role of coevolution of digital procurement readiness by the buyer and supplier in the adoption of digital procurement practices. This interdependency could result in coercive pressures for adoption in certain types of relational contexts.

Defined as the technology solution that facilitates corporate buying through the Internet (Presutti, 2003), e-procurement has been widely considered in the literature. However, with a few exceptions (e.g. Wu et al., 2007), the discussion of contextual variables that drive adoption has been somewhat atheoretical. In the literature, several contingency factors may be observed and categorised as external or internal to the firm and internal to the procurement function according to the authors' interpretations. Although the rather scarce evidence regarding external environment hints at the role of dynamism in determining e-procurement adoption (Walker and Harland, 2008), the internal firm factors are more diverse, emphasising, for example, the role of top management support (Teo et al., 2009), culture (Tatsis et al., 2006) and absorptive capacity for learning (Wu et al., 2007). Internal procurement factors seem to emphasise task-technology fit (Goodhue and Thompson, 1995), with manual and large volume tasks calling for efficiency-oriented e-procurement solutions. Large numbers of ad hoc solutions (e.g. spreadsheets; Doherty et al., 2013), suggesting complexity (Duncan, 1972), and supplier participation (Purchase and Dooley, 2010) have the same effect. 
Somewhat balanced in terms of the extent of coverage in the literature with contingency factors are the institutional factors. Public policy or regulation and business partner influence may be interpreted as coercive pressure (Doherty et al., 2013; Teo et al., 2009), and the perception of competitors' success and adoption may result in mimetic pressure (SoaresAguiar and Palma-dos-Reis, 2008), whereas public procurement functions may feel normative pressure from the more dynamic private sector (Doherty et al., 2013). Thus, eprocurement adoption takes place for external legitimacy.

Interestingly, the literature quite saliently suggests perceived benefits as a key driver for eprocurement adoption (e.g. Ronchi et al., 2010; Smart, 2010; Purchase and Dooley, 2010; Doherty et al., 2013; Toktaş-Palut et al., 2014). While this may indeed reflect expressed managerial mental models, true to the a priori structure (CIM), it is important to understand the underlying contextual variables or root causes that lead managers to perceive such benefits as lucrative.

This somewhat problematic saliency of perceived benefits as drivers for e-procurement adoption triggers a consideration of yet another relevant theoretical lens. Strategic choice theory builds on contingency theory but argues that decision makers essentially decide upon courses of strategic action and set performance standards while taking the environment into consideration (Child, 1972). As Shook et al. (2009) point out, the strategic choices of the firm, for example regarding prioritisation of savings, innovation or sustainability, potentially influence and determine sourcing decisions, as the procurement function may or may not fully align its strategic priorities with the competitive priorities and strategic initiatives of the firm (Baier et al., 2008). Thus, contingencies such as corporate or functional strategic initiatives break free from the deterministic nature of contingency theory (cf. Bals et al., 2018), and strategic choice theory provides a suitable explanation for example for a situation where the quest for efficiency and savings drives digitalisation.

Finally, intervention adoption rate driving factors, such as the availability of proven solutions (Doherty et al. 2013) and the uncertainty regarding technology and its benefits, as well as level of technology development (Tatsis et al., 2006) are noted. These aspects fall into the domain of innovation diffusion theory (e.g. Rogers, 2010), which proposes that technology adoption takes place in contexts where information about the returns from the utilisation of a specific technology becomes more widely available. As more organisations adopt the technology, the knowledge about the true returns is disseminated, resulting in an increased number of adopters due to, for instance, bandwagon pressure (Abrahamsson and Rosenkopf, 1993).

\subsection{Response variables of procurement technology adoption}

Firstly, in this research, interventions are defined as digital applications or the use of technologies of digitalisation to address problematic contexts and enable procurement value drivers (Srai and Lorentz, 2019; Hartmann et al., 2012). Comprehensive taxonomies of digitalisation applications in procurement do not yet exist, though some examples of digital applications have been described in the literature (Sanders, 2016; Handfield et al., 2019). 
Therefore, observation of the procurement digitalisation phenomenon may benefit from understanding the more abstract and high-level categories of e-procurement applications. Several forms are suggested by de Boer et al. (2002), including a categorisation that includes web-based ERP, e-sourcing, e-tendering, e-reverse auctioning and e-informing. At a more abstract level, Johnson et al. (2007) reveal a two-dimensional framework for e-procurement, namely transactional technologies for improving existing business processes and relational technologies for supporting the strategic integration of partners. Interventions in the domain of procurement digitalisation may be expected to relate to similar broader dimensions; however, a more general technology categorisation may also inform empirical analysis.

In this vein, despite tremendous advances in information and digital technologies, the literature from 20-30 years ago remains potentially informative. For example, Huber (1990) suggests basic information technology characteristics to pertain to data storage, transmission and processing capacities, with properties related to the facilitation of communication and decision aiding. Furthermore, within the theoretical domain of task-technology fit, Zigurs and Buckland (1998) define a typology of group support systems technologies. Firstly, communication support tools are defined as 'any aspects of the technology that supports, enhances, or defines the capability of group members to communicate with each other'. Secondly, process structuring technology 'supports, enhances, or defines the process by which groups interact' and corresponds closely with the concept of process workflows in operations management. Thirdly, information processing technology provides the capability to 'gather, share, aggregate, structure, or evaluate information' (Zigurs and Buckland, 1998, 320-321). In the context of inter-organisational systems, Kumar and van Dissel (1996) propose a typology along the dimension of interdependency, classifying such systems as pooled information resources, value/supply chain and networked systems. The respective technologies that power these systems are defined as mediating (e.g. shared databases), longlinked (e.g. EDI) and intensive (e.g. CAD data interchange; see also Thompson, 1967).

Secondly, mechanisms may be defined as new states or capabilities triggered by the intervention (Denyer et al., 2008), that is, something that can now be done differently in order to achieve the final performance outcomes. As the literature on procurement digitalisation is in a nascent state - and thus the response variables related to this phenomenon are largely uncharted - there is room for exploration. Nevertheless, the emerging mechanisms as a result of this research may, to some degree, be expected to relate to capability improvement in the areas of procurement value drivers, such as those identified by Srai and Lorentz (2019) for the digitalisation context: transaction management, coordination and control, process improvement and innovation, alignment, supplier capability assessment, relationship management and supply market knowledge management. Alternative perspectives on such drivers are offered by Hartmann et al. (2012), including supplier management, crossfunctional integration, strategy development, human resource management and controlling.

Empirical studies focusing on the perceived benefits from e-procurement indicate that the mechanisms may relate to, firstly, efficiency inducing practices and capabilities, such as reduction of maverick buying (Ronchi et al., 2010), introduction of common processes through harmonisation (Smart, 2010), task improvement (Purchase and Dooley, 2010) and 
simplification of processes (Toktaş-Palut et al., 2014). Many of these aspects seem to be supported by reported benefits by Croom and Brandon-Jones (2007), who also emphasise the improved internal service quality by procurement as a driver for greater internal compliance, resulting in lower total costs of acquisition.

Secondly, greater visibility and transparency (Ronchi et al., 2010; Toktaş-Palut et al., 2014) and improved and even real-time monitoring and reporting (Smart, 2010) relate to the enhancement of control-related capabilities, again supported by the findings of Croom and Brandon-Jones (2007). Thirdly, e-procurement may also provide a basis for capabilities for broader value contribution, based on knowledge and market intelligence sharing, as well as collaboration and integration (Smart, 2010; Toktaş-Palut et al., 2014; see also Croom and Brandon-Jones, 2007). Finally, literature suggests the enhanced capability for supply base management in the form of rationalisation and supplier selection (Ronchi et al., 2010; Smart, 2010).

In conclusion, the CIM logic is proposed as an a priori structure for our attempt to provide a broader and structured view on the procurement digitalisation by establishing linkages between specific contexts and response variables (Figure 1). The linkages between the elements can be illustrated as follows: external dynamism in the form of a large and variable supply base (C) drives the adoption of technologies to implement a more structured process for supplier selection (I), which improves the capability of the company to assess suppliers' capability (M).

Context variables of the procurement function

Context
The problematic context driving procurement
digitalization, external and internal environment
- Variables from contingency theory; external and
internal contingencies: complexity and dynamism
(Duncan 1972; Souza and Voss 2008; Ellram et al.
2002; Bals et al. 2018)
- Variables from institutional theory: coercive, mimetic
and formative pressure (DiMaggio and Powell 1983;
Zsidisin et al. 2005)
- Variables from the strategic choice theory: priorities
regarding for instance savings, innovation or
sustainability (Child 1992; Shook et al. 2009)
- Variables from innovation diffusion theory (Rogers
2010; Doherty et al. 2013)

Response variables in the procurement function

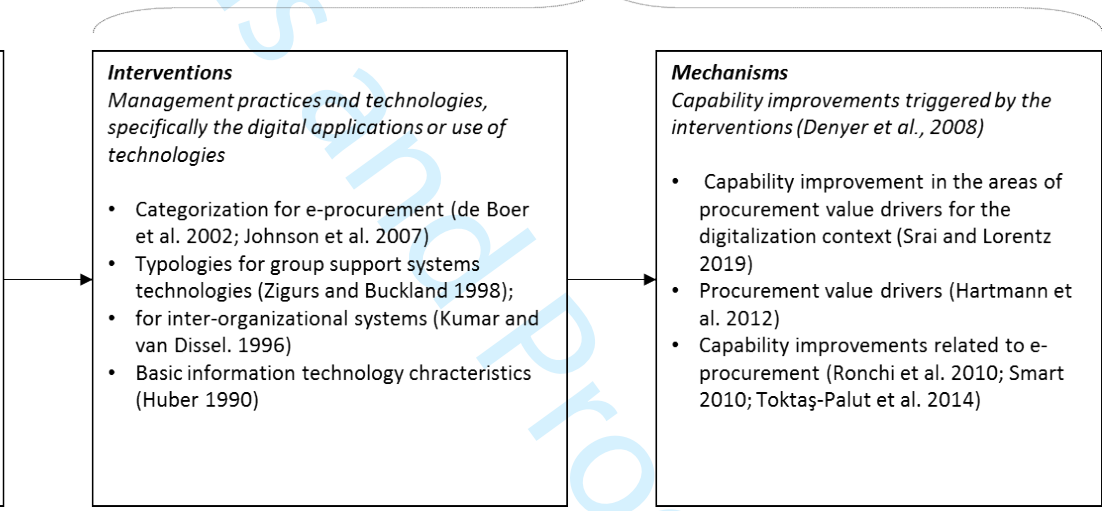

Figure $1 \quad$ CIM-logic as an a priori structure: theoretical foundations for contexts and response variables

The above literature review, firstly, selectively covered prominent theoretical perspectives and, secondly, drew useful points of departure from the e-procurement literature for understanding the context and response variables. With an appropriate level of preunderstanding regarding the 'potentially important constructs' thus developed (Eisenhardt, 1989), theoretical foundations have been set for the exploratory case study, the process of which is elaborated in the following.

\section{Methods}




\subsection{Research design and case selection}

A case study design is suitable for the forward-looking approach because it enables identifying emerging themes and patterns and acquiring rich and detailed data of the mental models (Eisenhardt and Graebner, 2007). In the case study approach, data collection allows for the use of multiple informants and clarification questions, which enable triangulation and facilitate a strong substantiation of constructs (Eisenhardt and Graebner, 2007). This study design enables managerially relevant knowledge to be generated due to the involvement of managers operating in real digitalisation projects (Gibbert et al., 2008).

The empirical study drew on data from 12 organisations. These case organisations were selected using theoretically motivated (Dubois and Araujo, 2007) intensity sampling (Patton, 2002) to include rich and sophisticated examples of the phenomenon of interest. Adhering to this principle, organisations where procurement is of high priority and have high learning potential for the researchers were searched (i.e. leading companies and public organisations). These case organisations apply advanced supply management methods and have demonstrated interest in the digitalisation of procurement. The organisations were selected from Finland, the leading EU country in digital performance in 2019 (European Commission, 2019). The unit of analysis (UoA) in this research is a digital application project, which is considered important for the organisation to advance procurement digitalisation. Altogether, 48 application projects were identified (see details in Appendix B) and comprised the case study data set.

To find and select case organisations according to the principles of intensity sampling, seven leading organisations known from previous research collaborations were invited to participate in the study, based on the maturity and resourcing of their procurement organisation (large firm, observed category management practices), as well as having procurement digitalisation on their strategic agenda. Secondly, the participants of two industry seminars on procurement digitalisation were approached. Amongst the participants (30 and 15 per seminar), three organisations were selected to act as cases, again based on the maturity and resourcing of their procurement organisation, their interest towards procurement digitalisation, as well as their willingness to commit to the study. Thirdly, based on an academic survey amongst Finnish companies on the status of procurement (see Lorentz et al., 2019), two more organisations were invited for the study, based on their response indicating completed or planned procurement digitalisation initiatives, and willingness to commit to the study. For these selected 12 organisations, their willingness to participate in the study and access to key informants were ensured to secure commitment and a high quality process for data collection. The overview of the case companies is presented in the Table I.

Table I Overview of the cases and data collection -Insert Table I approximately here

\subsection{Data collection}


The main data collection method was semi-structured interviews with knowledgeable managers in the organisations. The interviewed individuals were selected on the basis of their position; all were in managerial positions in procurement and involved hands-on in the digitalisation of this function. The interviews were conducted by two or three researchers (researcher triangulation) who met the interviewees individually or in pairs/groups. All participating organisations were covered with more than one interview or a second engagement in the form of a workshop, thus enabling source triangulation and strengthening overall research quality. The interviews were recorded and transcribed, and interviewers took notes. A semi-structured interview protocol guided the discussion towards the objectives of the interview, including (1) mapping the adopted or planned digital applications (e.g. spend analytics) and (2) disclosing the nature (e.g. cloud-based), aims (e.g. improved control), implications and fundamental reasons (e.g. complex multi-unit organisation) for the implementation of such applications, thus covering the entire CIM spectrum. The adopted interview format also gave the researchers the flexibility to focus on unique features in each case (see Appendix A). Assisted by a digitalisation grid (Srai and Lorentz, 2019) defined by technologies and value drivers, the interviewees were asked to point out the most important digital applications. The grid was used to identify and explain applications along the a priori CIM dimensions. This phase was interactive in nature; the researchers explained the terms when needed to ensure a univocal understanding of each construct, gave instructions and asked detailed questions when necessary.

In addition to interviews, a workshop was arranged with the interviewed procurement managers to validate and complement the preliminary findings. The three-hour workshop was attended by nine managers from several case organisations and three researchers. The participants were asked to enrich the understanding on the links between contexts, interventions (specific digital technologies) and mechanisms.

\subsection{Data coding and analysis}

The data, including the interview transcripts, the filled-in digitalisation grids and the workshop transcripts, were analysed within cases and across cases (Miles and Huberman, 1994; Yin, 2009). The a priori defined CIM elements formed the basic structure while the interview data were utilised to add rich content to the framework. Data coding and analysis was an iterative process in which the phases alternated, including systematic coding, frequent face-to-face discussions amongst the three involved researchers, generation of different data displays, visual projections of coding results and summary of results.

The transcribed data were coded with NVivo software. The first phase started with a test round, in which two researchers coded one interview transcription, and comparisons were made to ensure similar interpretations of the key constructs. After adjustments, each interview was coded by at least two researchers to identify the UoA for each case organisation from the data and create a description of the units along the elements of the CIM a priori structure. A total of 48 units were identified, with reduced form data describing the analysis unit in appropriate level of detail arranged into a data display (Appendix B). This phase essentially constitutes the within-case analysis of the research. 
In the second phase, a cross-case analysis was conducted by observing the UoA across each element of the CIM a priori structure. Emergent themes in each were abductively compared and matched with the earlier covered theories (Dubois and Gadde, 2014) and thus create higher-order themes and theoretical constructs. Having advanced from case specific details to a more abstract and theoretical level within each of the CIM element, patterns were then observed in terms of how these elements were connected by sorting the data display. This exploratory sorting broke down the abductively matched constructs and brought further clarity into linkages, allowing the development of propositions as procurement digitalisation strategy options.

\section{Results}

\subsection{Identification of categories within CIM elements}

In the following, the results of analysis across the entire data set are presented, starting with the analyses of each of the CIM elements. This was based on abductive matching of the observations from the data with the theoretical perspectives presented previously. The results regarding contexts are presented in Table II, interventions in Table III and mechanisms in Table IV.

In this research, context is considered as a driver or a cause for procurement digitalisation, with external and internal environment-related contingencies appearing as strong drivers of digitalisation interventions. Major identified context subcategories are external dynamism, external complexity and internal complexity (Duncan, 1972), with Table II presenting representative examples from the empirical data. Furthermore, the strategic choices made by the organisation's decision makers (cf. Child, 1972) seem to drive some of the digitalisation interventions. Here, the organisation's strategic choice for savings and efficiency was identified as a strong driver for digitalisation. Other decision makers' strategic choices that seemed to influence the digitalisation interventions are presented in Table II. As a third context category, reflecting institutional isomorphism (DiMaggio and Powell, 1983), coercive and normative pressure seems to drive digital interventions in the case organisations (Table II). By contrast, innovation diffusion theory did not seem to explain the drivers for procurement digitalisation in the data set.

Moving on to digital interventions, we observed that the typology for group support technologies by Zigurs and Buckland (1998) fits the structure perceived in the data set. Therefore, the interventions were categorised as communication support, process structuring and information processing interventions. These categories were further classified to subcategories (Table III) to better match the observations from the data. The data set also included interventions that fit the concept of decision aiding (Huber, 1990).

The observed structure related to mechanism seemed to fit well with the value driver framework suggested by Srai and Lorentz (2019), including transaction management, coordination and control, process improvement and innovation, strategic alignment, supplier capability assessment, relationship management and supply market knowledge management. Table IV presents representative examples of the data related to the mechanisms. 
Table II Contexts with representative examples from the data

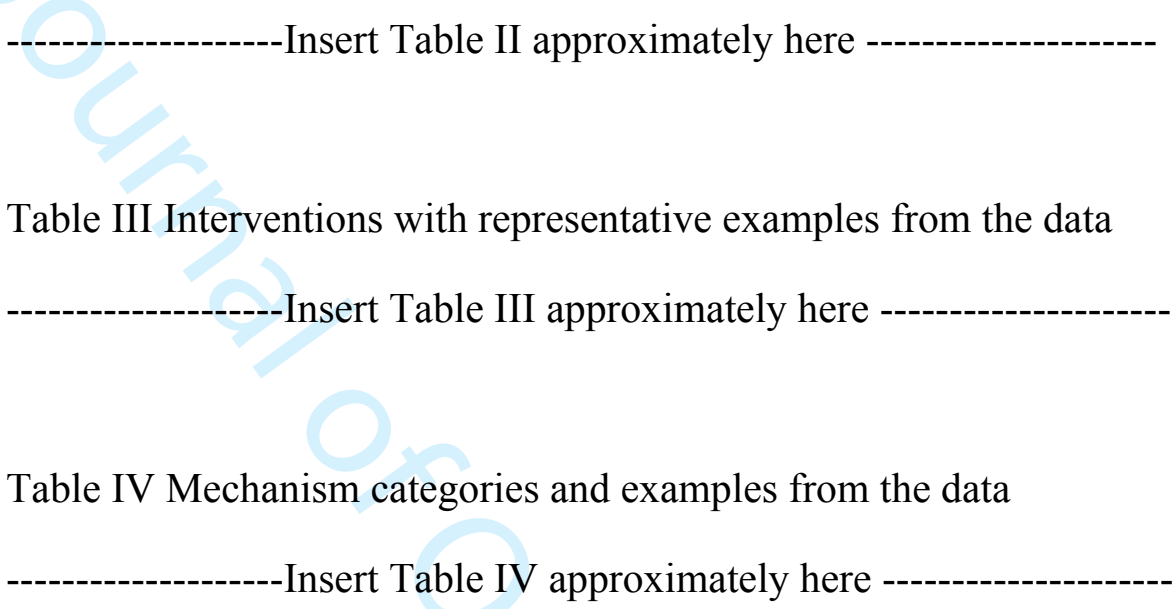

\subsection{Propositions on linkages between CIM elements}

In this section, a set of propositions were developed reflecting the abductively perceived constructs and their linkages in the data set either across all the CIM elements or only between two elements (e.g. IM). To support the development and discussion of propositions, Figure 2 was used to focus attention on the relatively salient linkages based on the frequencies between the CI and IM elements, as observed in the data display in Appendix B. Those linkages with a frequency equal to or above a threshold of three (directs attention to max. $50 \%$ of all the linkages), were selected for further consideration for proposition development; nevertheless, a closer examination in some cases caused relaxation of this rule. After the salient linkages for potential proposition development were identified, these were examined in more detail for actual associations (see data display in Appendix B). For example, after closer examination, two different institutional pressures (external coercive and normative pressures), driving data storage and management (Figure 2: L5 and M5, panel A) were treated together in a proposition despite their low frequencies individually, as they both serve as drivers for producing external legitimacy. Furthermore, although data storage and management are linked with a frequency of three with coordination and control (Figure 2: E2, panel B), the evidence on related linkage with the context is mixed, and thus proposition development was not pursued further. Essentially, some judgement was used to decide on the potential for proposition development. In the following, the resulting propositions are developed and discussed (highlighted with colour codes in Figure 2) with references to the appropriate units of analysis (see Appendix B). 

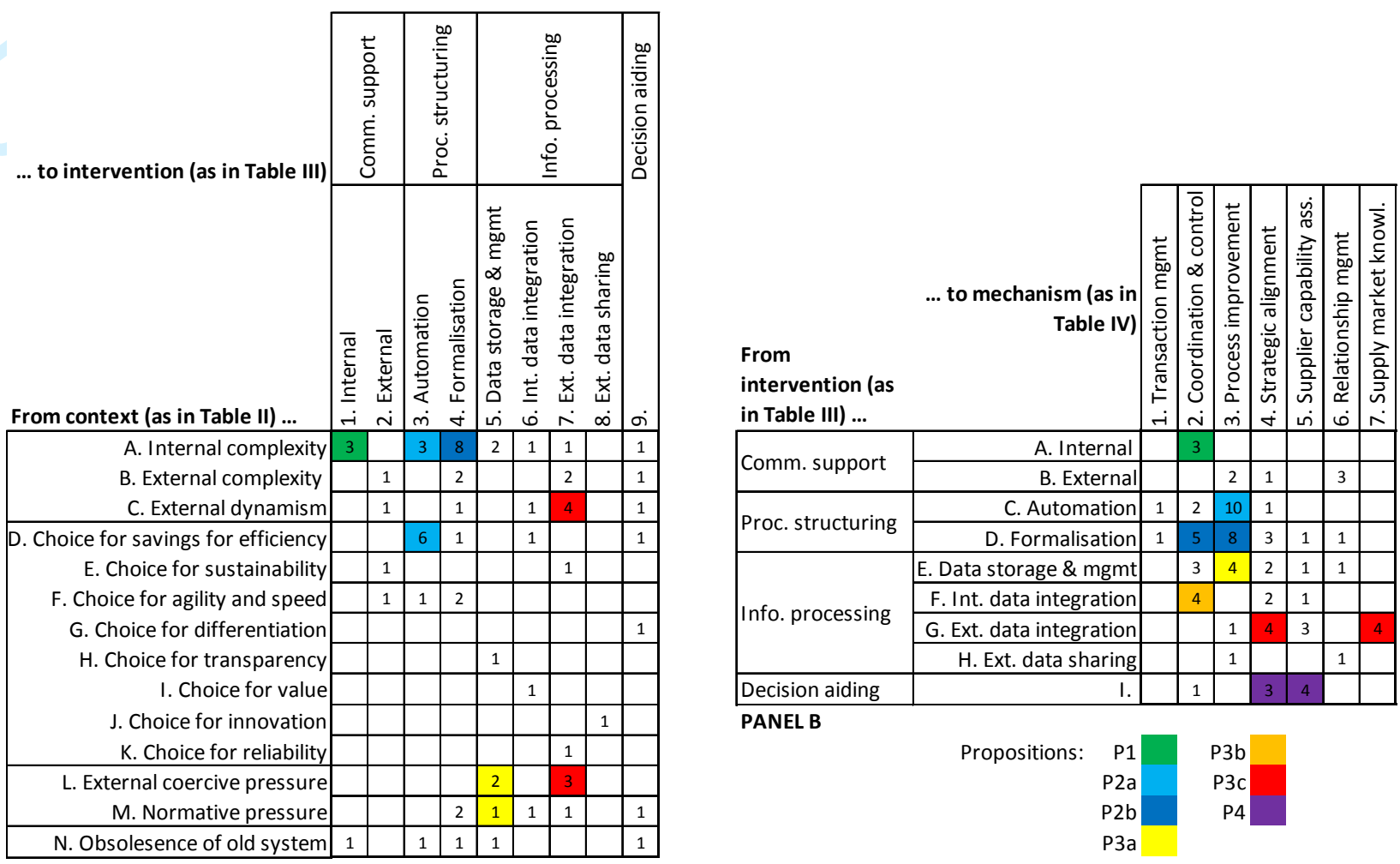

PANEL A

Figure 2 Data display of the frequencies of CI linkages (panel A) and IM linkages (panel B)

Interventions for internally oriented communication support, for example social media platforms used for communicating and informing about system updates and procurement policies across the organisation and stakeholders, are predominantly observed. Internal complexity stemming from (1) a large number of stakeholders, especially in the case of indirect procurement, (2) multiple organisational units and (3) many different legacy information systems (Appendix B: 3, 27, 33), seem to drive uncertainty across the organisation (Duncan, 1972) and affect procurement tasks (cf. Foerstl et al., 2018). Therefore organisations are expected to match such uncertainty-driven requirement with more information sharing, produced with increased capacity for communication within the organisation (Galbraith, 1977; Tushman and Nadler, 1978). Communication support interventions in the form of social media platforms may be ideal at reducing internal complexity-driven uncertainty owing to their capacity to communicate large quantities of data (Figure 2: A1, panel A).

It is likewise observed that internally oriented communication support interventions are linked with the coordination and control mechanism for policy compliance and greater visibility into contracts provided by strategic sourcing (Appendix B: 3, 27, 33) with a remedial effect on maverick buying (Figure 2: A2, panel B). The interpretation of this linkage is supported by Kauppi and van Raaij $(2015,953)$, who suggest that 'guidance and training help to reduce governmental employees' noncompliance' regarding centrally negotiated frame agreements because internal social media may support such efforts for guidance. Therefore, the following proposition is suggested. 
P1: Internal complexity contexts $(\mathrm{C})$ regarding multiple stakeholders and multi-unit organisations, drive internal communication support interventions (I) with social media platforms supporting coordination and control mechanisms $(\mathrm{M})$ for policy compliance.

Moving on to process structuring interventions, initially on those with automation orientation, it is observed that these primarily draw on robotic process automation technology for data transfer between systems, invoice handling, contract implementation and supplier validation (Appendix B: e.g. 3, 14, 22, 28). Further observations on the reduced form of data in Appendix B suggest that such interventions are typically driven by the context variable of strategic choice for savings and efficiency along with internal complexity (Figure 2: D3 and A3, panel A). Regarding the latter, the complexity due to many internal stakeholders, several separate systems and multi-unit organisation creates a ripe context for applying robotic process automation to large volumes of repetitive, error-prone and rule-based tasks, including those with a swivel-chair nature for integrating separate systems (Fung, 2014). Coupled with a strategic choice for savings and efficiency at the firm level, automation likely becomes part of the procurement strategy (cf. Säfsten et al., 2007).

The link from automation-oriented interventions to the mechanism side is quite straightforward, as it is observed that process structuring via automation most prominently results and is aimed at process improvement (Figure 2: C3, panel B), which takes place through process renewal, release of resources for more strategic tasks, reduced amount of mistakes, faster contract formulation and easing the burden of sourcing managers (Appendix B: e.g. 1, 3, 23, 39). The observations based on data set therefore suggest the following proposition.

P2a: Strategic choice for savings and efficiency and internal complexity contexts (C) drive automation-oriented process structuring interventions (I), which typically support process improvement mechanisms (M) leading to shortened cycle times, efficient use of procurement resources and error reduction.

Similarly to automation, formalisation-oriented process structuring interventions also appear to be driven by internal complexity, but even more saliently (Figure 2: A4, panel A). Multiunit organisations, multiple stakeholders and heterogeneous spend, particularly in the domain of indirect procurement, drive the need for clear operating procedures harmonised across units and sites (Appendix B: e.g. 6, 13, 16, 20, 29), thus enabling the achievement of synergies (cf. Rozemeijer, 2000). Such formalisation has been suggested to contribute to the level of procurement maturity (Bals et al., 2018) and that formalisation-oriented process structuring interventions respond to internal complexity. In the data set, interventions typically come in the form of software-as-a-service (SaaS)-based platforms for broadly supporting sourcing processes and projects (e.g. supplier onboarding and management, tendering, RFx, e-auctions, savings registering), supplier collaboration and stakeholder buying through, for example, e-catalogues (Appendix B: e.g. 5, 12, 18, 20).

These interventions (Appendix B) typically aim at the mechanisms of coordination and control and process improvement (Figure 2: D2 and D3, panel B). In the data set, 
coordination and control as a result of process formalisation come in the form of harmonisation, better use of contract terms, buying based on accepted requisitions, improved linking of contractor work reports with contracts and reduction of maverick buying (Appendix B: e.g. 1, 16, 20). Indeed, limiting task autonomy has been shown to reduce maverick buying (Karjalainen and van Raaij, 2011). Moreover, process improvement as a result of formalisation shows in the data as an accessible single site for sourcing tasks, process throughput time reduction, redirection of resources to more strategic tasks and improved category management (Appendix B: 5, 6, 30). These observations are aligned with research that suggests formalisation, by means of rules, procedures and protocols, improves the effectiveness of, for example, global teams (Gibson et al., 2019). Source-to-contract platforms may essentially be perceived as providing such in the procurement context. The following proposition is thus suggested.

P2b: Internal complexity contexts (C), such as in the form of multi-unit organisations, multiple stakeholders and heterogeneous spend, drive process structuring interventions (I) for formalisation, typically supporting coordination and control (for improved contract utilisation and harmonisation) and process improvement mechanisms (M) (for efficiency and speed).

The third identified intervention category is related to information processing and covers three subcategories as discussed earlier. All the intervention categories focus on data, with the first on the aspect of data storage and management. These types of interventions range from simple network drives to more advanced data warehouse infrastructures, as well as from automatic collection and deletion of data points by means of robotic process automation to artificial intelligence-based contract content categorisation and labelling (Appendix B: 7, 8, 19, 30). RPA applications include automatically including suppliers' product information in an e-commerce system for the benefit of consumers or deleting unused suppliers' data from databases in compliance with GDPR regulation (Appendix B: 11, 8). Other contextual variables that serve as drivers for adoption include regulation regarding product information availability, such as coercive pressures, as well as a perceived 'quest for sourcing excellence' (Appendix B: 8, 11,30), which may be understood as pertaining to normative pressures (Figure 2: L5 and M5, panel A). Similarly, the role of such institutional pressures in the adoption of Internet-enabled systems for supply chain management (e.g. Liu et al., 2010) and the nature of GDPR regulation as coercive pressure in data collaboration (van den Broek and van Veenstra, 2018) have been recognised in extant research.

Information processing interventions for data storage and management aim for process improvement and strategic alignment (Figure 2: E3 and E4, panel B), with error free, up-todate and compliant databases supporting category management and consumer-facing strategies for transparency in e-commerce (Appendix B: e.g. 7, 8, 11). Therefore the following proposition is stated.

P3a: Institutional pressures contexts (C) in the form of coercive data regulation or normative pressure for excellence, drive information processing interventions (I) for automatic data storage and management, which supports process improvement mechanisms (M) for increased compliance and transparency. 
As discussed earlier, the interventions for internal data integration seek to combine high volume, variety and velocity of data from heterogeneous internal sources to enable improved decision making in the organisation (e.g. Nadal et al., 2019; Waller and Fawcett, 2013). In the procurement context, the data set in Appendix B prominently describes advanced spend data applications and suggests relevance for evaluating supplier performance on cloud-based analytics platforms (Appendix B: 2, 26, 32, 35). The advanced forms of spend analytics draw on algorithms for data improvement, provide real-time monitoring capabilities and combine spend data internally with contract and order data to enable forward-looking spend planning in contrast to the typical rearview mirror perspective. The context variable drivers for these interventions seem to vary somewhat, preventing conclusions regarding prominent drivers (Figure 2: column 6, panel A). Drivers such as effort to secure savings, complex multi-unit organisation and aim for fact-based procurement are observed (Appendix B: e.g. 2, 32).

However, at the mechanism side, the picture is clearer, suggesting, quite logically, coordination and control as the prominent output (Figure 2: F2, panel B). This is achieved by the means of better capability for steering and achievement of a global or 'helicopter' view on spend (Appendix B: 35), allowing the detection of synergy opportunities across business units and supply markets (Faes et al., 2000). Thus, interventions that support the spend analysis process and related decision making result in coordination for global synergies in procurement (Smart and Dudas, 2007). The following proposition is therefore stated.

P3b: Information processing interventions (I) for internal data integration, such as for spend management, typically enhance coordination and control mechanisms (M) in support of steering and global synergy (M).

Interventions for external data integration seek to combine high volume, variety and velocity of data from heterogeneous internal and external sources. Such big data ecosystems may enable organisations to leverage situational data analysis, with data obtained, for example, from third-party data providers (Nadal et al., 2019) or, in the procurement case, from suppliers. Appendix B describes such interventions as cloud-based systems and tools for collecting, combining and analysing internal spend data, supplier performance data and external supplier financial status data, commodity prices, country risk indicators, news feeds and even possible court records for suppliers' key personnel background checks (Appendix B: e.g. 9, 15, 45, 46). Interventions may also be geared towards enabling an examination of suppliers' compliance with, for example, the REACH regulation regarding their products and components (Appendix B: 42). The data set also shows that the contextual variables as drivers pertain predominantly to external dynamism (Figure 2: C7, panel A), for example in terms of changing supply markets (e.g. consolidation, volatile market prices) and dynamic supply bases (mergers, production transfers, PLC ramp-downs; Appendix B: e.g. 36, 45). Such characteristics drive uncertainty and, therefore, according to the information processing theory, suggest a greater amount of information processing that must be matched with an appropriate capacity for processing (Galbraith, 1977; Tushman and Nadler, 1978).

Information systems as interventions provide such a capacity by being able to process large quantities of data (Daft and Lengel, 1986). Additionally, external coercive pressure in the form of REACH, traceability and security regulation (Appendix B: 15, 17, 42) drive the 
uptake of interventions for integrating external data (Figure 2: L7, panel A). This phenomenon may be linked to the more general adoption of responsible and ethical practices, which are often driven by institutional pressures (Waddock et al., 2002).

Aligned with information processing theory (Galbraith, 1977; Tushman and Nadler, 1978), the mechanisms enabled by this type of information processing capacity that increases interventions relate to an improvement in supply market knowledge (Figure 2: G7, panel B) in the form of an efficient access to enhanced intelligence and supply market visibility. It is also linked to a strategic alignment for compliance in the form of traceability and meeting public expectations for ethical practices (Figure 2: G4, panel B). Other business benefits appear to include, for instance optimisation of food supply chain for less waste and recalls, enabled by a blockchain application for transparency in terms of food sources (Appendix B: 4). The following proposition is therefore suggested.

P3c: External dynamism (e.g. regarding supply markets) and coercive pressure contexts (C) (e.g. in the form of regulation), drive information processing interventions (I) for external market data integration, which typically support supply market knowledge and strategic alignment mechanisms (M) for enhanced compliance.

Interventions for decision aiding is the final category discussed in this section. As was observed earlier, no subcategories are detected in the data because the number of analysis units is relatively low (6). It seems that the contextual variables as drivers (Appendix B) are quite heterogeneous without a common denominator (Figure 2: column 9, panel A). For example, the following is observed: (1) internal complexity is mentioned as a driver for workplace-social media application for rating suppliers, (2) external complexity due to heterogeneous spend and suppliers appears as a driver of artificial-intelligence-based prescriptive analysis for supporting sourcing decisions and (3) normative pressure in the form of aim for fact-based decision making functions as a driver of intelligent anomaly alerts regarding supplier performance (Appendix B: 3, 9, 31). Prescriptive analytics or artificial intelligence applications form the technological basis for such interventions. Therefore, in the early maturity phase of the technology, the drivers are more or less firm specific because of the lack of use cases, low availability of off-the-shelf applications and low degree of innovation diffusion (Rogers, 2010). Such conditions discourage firms to broadly board the bandwagon of intervention adoption for decision aiding (Abrahamsson and Rosenkopf, 1993).

By contrast, the linkage to the mechanism side is somewhat clearer, as supplier capability assessment and strategic alignment seem to be dominant aims of decision-aiding interventions (Figure 2: I4 and I5, panel B). Regarding the former, the interventions enable supplier performance ranking, risk profiling and predicting on-time-delivery performance (Appendix B: 3, 9, 41), whereas in terms of the latter, the data set suggests improved capability for evidence-based category management and cost reduction (Appendix B: 2, 31). The following proposition is therefore suggested. 
P4: Firm-specific contexts (C) drive decision-aiding interventions (I) with artificial intelligence and predictive analytics, supporting, for example, supplier capability assessment mechanisms (M) for improved on-time delivery and risk mitigation, and strategic alignment mechanisms (M) for enhanced category management.

Figure 3 depicts the developed propositions across the CIM elements.

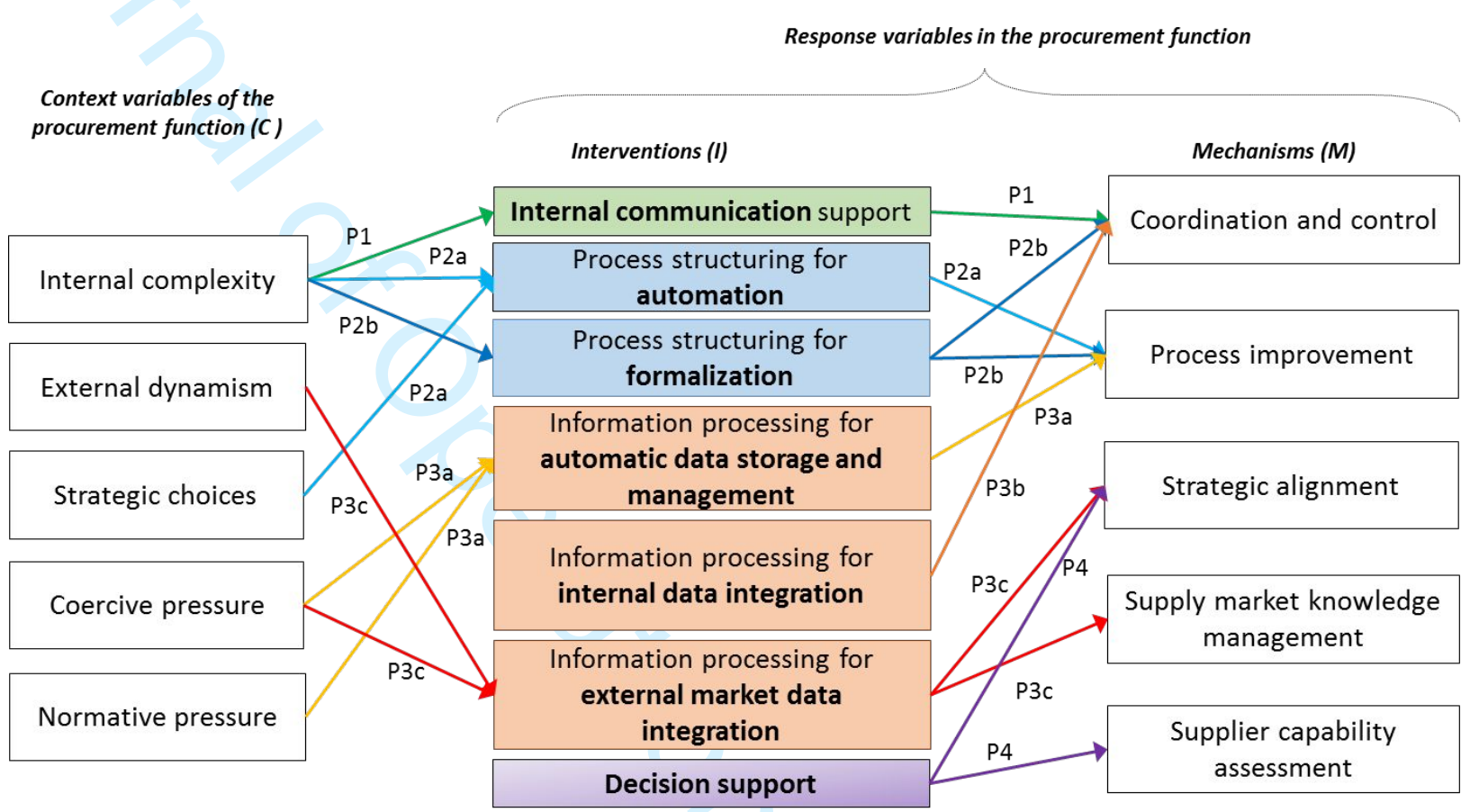

Figure 3 Linkages between context variables and response variables as stated in propositions

\section{Discussion and conclusions}

\subsection{Theoretical implications}

In pursuing to structure the phenomenon of procurement digitalisation, this research presented a rich picture of the dominant managerial mental models or cognitive representations regarding the business environment where decision makers act to manage systems and organisations (Daft and Weick, 1984; Porac and Thomas, 1990). The theoretical implications of this research may be roughly divided into two categories.

Firstly, the results provide structure to each of the elements of the CIM a priori structure, broken down into categories, with empirical observations abductively matched with extant theoretical constructs in the literature. The data show that context as the driver of digital interventions in procurement may be explained with (1) contingency-theory-related constructs of complexity and dynamism as characteristics of procurement and supply markets (Duncan, 1972); (2) various strategic choices aligned with corporate strategic imperatives such as savings and sustainability (Child, 1972); and (3) institutional pressures instigated by, 
for example, coercive regulation and normative perceptions about procurement excellence (DiMaggio and Powell, 1983). These results are not unexpected, as some of these theories have been used to examine contextual variables in the procurement context before (Zsidisin et al., 2005; Bals et al., 2018). However, the results suggest the dominance of certain categories of drivers, such as internal complexity and choice for savings and efficiency, in the pursuance of procurement digitalisation.

At the intervention side, the abductive analysis matched empirical observations with extant technology categories in the literature (Zigurs and Buckland, 1998; Huber, 1990), allowing the advance from referring to particular technologies, such as robotic process automation or artificial intelligence, to a more abstract and theoretically interesting level of examining the procurement digitalisation phenomenon. The data reveal that procurement digitalisation interventions are first and foremost about process structuring in the form of automation and formalisation as well as information processing in the form of integrating external and internal data for leveraging analytics in decision making. With such interventions, procurement decision making becomes more situational (Nadal et al., 2019), timely and confident, with potentially beneficial effects on involvement in cross-functional and strategic deliberations (e.g. Zsidisin et al., 2005).

For structuring the mechanism side, the data appeared to match appropriately with the procurement value drivers identified by Srai and Lorentz (2019). Interestingly, the most prominent mechanisms in the data appear to be (1) process improvement, (2) coordination and control and (3) strategic alignment. According to Srai and Lorentz (2019), these drivers may be considered predominantly internal in nature, suggesting bias in the mental models towards internal development, rather than aiming at more externally oriented supplier capability assessment, relationship management and supply market knowledge. While the subsequent proposition development in the domain of CIM linkages covers almost the entire range of element categories, both internally and externally oriented, we note that the main thrust of procurement digitalisation, as reflected in our data set, appears to have a predominantly internal flavour. Specifically, it represents internal complexity and choice for efficiency at the context side; automation and formalisation of processes at the intervention side; and coordination and control, process improvement and strategic alignment at the mechanism side. Integration of data sources for information processing, including those external in nature, seems to be an exception to this pattern of internal bias in procurement digitalisation mental models. Given the proposed dyadic nature of procurement digitalisation (Kosmol et al., 2019), that is, adoption in sync with suppliers, the dominant results presented here provide an interesting contrast to the more externally oriented mental models that may appear in specific contexts.

Secondly, the theoretical contributions come in the form of seven propositions regarding the linkages between element categories within the CIM a priori structure. The seven propositions may be conceptualised as managerial mental models. From the observations across these propositions, it seems that internal complexity, as previously suggested, appears to be a salient driver for procurement digitalisation, motivating (1) internal communication support, (2) automation-oriented process structuring and (3) formalisation-oriented process 
structuring interventions, which in turn aim at procurement coordination and control as well as process improvement. This is a prominent mental model (P1, P2a, P2b; see also P3b) an with internal orientation (cf. Søgaard et al., 2019), which, if realised with digitalisation, enables procurement to reduce operating cost, serve stakeholders faster and more reliably and achieve higher spend-under-management ratios across categories. These basic but rather important internal aims thus remain on the procurement development agenda (cf. Cox et al., 2005) and may be potentially addressed with digitalisation.

In contrast to the internal mental model, another cross-proposition observation is that external forces such coercive regulatory pressures and external dynamism drive interventions for information-processing-related (1) automatic data storage and management, (2) external market data integration and interventions related to (3) decision aiding. These interventions seem to be linked with mechanisms such as process improvement (P3a), supply market knowledge and strategic alignment for external compliance (P3a, P3c) and supplier capability assessment (P4). This prominent mental model therefore demonstrates a more external orientation and will potentially enable procurement to leverage intelligence on suppliers and supply markets. Consequently, it will increase its involvement in cross-functional decision making (Zsidisin et al., 2015) and the strategic relevance of the function (van Weele and van Raaij, 2014). Improved capability to tap into the supply base and market knowledge may enable the procurement function to draw on both exploitation- and exploration-oriented development efforts and simultaneously improve the existing as well as adopt novel sourcing arrangements and supply solutions in a balanced way (Kilpi et al., 2018). Furthermore, efficiently meeting the requirements imposed on the organisation by external parties, for example in terms of sustainability, enables the procurement function to support broader corporate objectives.

\subsection{Managerial implications}

The structured picture of the phenomenon of digitalisation in procurement gives guidelines for managers when considering procurement digitalisation in their specific contexts. The study identifies categories of contexts in which specific choices of digital technologies are common and links to specific mechanism categories. For example, a desire to achieve savings in company operations was identified as a strong driver for digitalisation, which may be realised in terms of adopting robotic process automation-based solutions for bringing about process improvement for efficiency outcomes. On the other hand, innovations may be a strategic choice for another company, and the achievement of such a goal may be supported by digital solutions related to enhanced external data sharing, with improved relationship management leading to innovation outcomes.

With critical assessment, the identified sets of variables, presented in the form of propositions, may be considered as digital strategies for procurement. Decision makers may then develop and refine such strategies further into case-specific root cause analyses, user journeys, technical specifications for vendors, roadmaps and expected outcomes with plans for measurement. Essentially, the results provide strategy options for decision makers to consider both in the contexts of procurement digital strategy development and evaluation. 
Here the results also allow for checking of a possible strategy bias towards, for example, the internally oriented digitalisation, which would leave the externally oriented unaddressed. Reflection on the organisation's context allows appropriate prioritisation and focus in the light of the results of this research.

\subsection{Limitations and future work}

In terms of limitations, this research focuses on mental models of procurement managers in 12 organisations in one country. Although case selection sought to employ purposeful sampling for a diverse set of organisations across manufacturing, retail, utilities and public domains, the eventual sample unavoidably suffers from a small size and some level of bias. In this vein, it is noted that our data did not provide salient enough evidence for linking all of the observed context variables and mechanisms with interventions (e.g. external complexity), thus suggesting the need for further research. Furthermore, this research suggests a structure for procurement digitalisation, which, as a mental model, can largely be considered a prediction because the phenomenon that is the focus of this research has not yet been realised at scale.

Despite these shortcomings, when addressed with careful research design, diversity in sampling and triangulation of researchers and sources during data collection and analysis, this research structures the field in a nuanced manner and offers a foundation for further exploration of the phenomenon in different environments. Replication studies may refine and enrich the results of this study, and longitudinal studies may capture change in this rapidly evolving domain for example in terms of shift from internal to external orientation. In further research, as digital applications in procurement become more common, and as the study and observation of realised contexts, interventions and mechanisms become possible, the knowledge base on procurement digitalisation can be validated and refined by testing the suggested propositions and expanding the scope to the achieved outcomes and their measurement.

Indeed, this novel forward-looking approach for structuring the phenomenon of procurement digitalisation may support procurement functions to seek, discover and experiment with new technology solutions. Only with such efforts can procurement possibly experience a transformation that will meet the expectations characterising the much discussed 'revolution scenario' for the procurement future.

\section{References}

Abrahamsson, E. and Rosenkopf, L. (1993), "Institutional and competitive bandwagons: Using mathematical modeling as a tool to explore innovation diffusion", Academy of Management Review, Vol. 18, No. 3, pp. 487-517.

Azadegan, A., Patel, P. C., Zangoueinezhad, A. and Linderman, K. (2013), "The effect of environmental complexity and environmental dynamism on lean practices", Journal of Operations Management, Vol. 31, No. 4, pp. 193-212. 
Baier, C., Hartmann, E. and Moser, R. (2008), "Strategic alignment and purchasing efficacy: An exploratory analysis of their impact on financial performance", Journal of Supply Chain Management, Vol. 44, No. 4, pp. 36-52.

Bals, L., Laine, J. and Mugurusi, G. (2018), "Evolving purchasing and supply organizations: A contingency model for structural alternatives", Journal of Purchasing and Supply Management, Vol. 24, No. 1, pp. 41-58.

Barney, J.B. (1991), "Firm resources and sustained competitive advantage", Journal of Management, Vol. 17, No. 1, pp. 99-120.

Busse, C., Kach, A.P. and Wagner, S.M. (2017), "Boundary conditions: What they are, how to explore them, why we need them, and when to consider them", Organizational Research Methods, Vol. 20. No. 4, pp. 574-609.

Child, J. (1972), "Organizational structure, environment and performance: The role of strategic choice”, Sociology, Vol. 6, No. 1, pp. 1-22.

Cox, A., Chicksand, D., Ireland, P. and Davies, T. (2005), "Sourcing indirect spend: a survey of current internal and external strategies for non-revenue-generating goods and services", Journal of Supply Chain Management, Vol. 41, No. 2, pp. 39-51.

Croom, S., \& Brandon-Jones, A. (2007), "Impact of e-procurement: experiences from implementation in the UK public sector", Journal of Purchasing and Supply Management, Vol. 13, No. 4, pp. 294-303.

Daft, R. L. and Lengel, R. H. (1986), “Organizational information requirements, media richness and structural design”, Management Science, Vol. 32, No. 5, pp. 554-571.

Daft, R. L. and Weick, K. E. (1984), “Toward a model of organizations as interpretation systems", Academy of Management Review, Vol. 9, No. 2, pp. 284-295.

De Boer, L., Harink, J. and Heijboer, G. (2002), "A conceptual model for assessing the impact of electronic procurement", European Journal of Purchasing \& Supply Management, Vol. 8, No. 1, pp. 25-33.

Denyer, D., Tranfield, D. and Van Aken, J.E. (2008), "Developing design propositions through research synthesis”, Organization Studies, Vol. 29, No. 3, pp. 393-413.

DiMaggio, P.J. and Powell, W.W. (1983), “The iron cage revisited: Institutional isomorphism and collective rationality in organizational fields", American Sociological Review, Vol. 48 No. 2, pp. 147-160.

Doherty, N. F., McConnell, D. J. and Ellis-Chadwick, F. (2013), "Institutional responses to electronic procurement in the public sector", International Journal of Public Sector Management, Vol. 26, No. 6, pp. 495-515.

Donaldson, L. (1987), "Strategy and structural adjustment to regain fit and performance: In defence of contingency theory", Journal of Management Studies, Vol. 24, No. 1, pp. 1-24. 
Donaldson, L. (2001), The Contingency Theory of Organizations, SAGE Publications, Inc., Thousand Oaks, CA.

Dubois, A. and Araujo, L. (2007), "Case research in purchasing and supply management: Opportunities and challenges", Journal of Purchasing and Supply Management, Vol. 13, No. 3 , pp. 170-181.

Dubois, A. and Gadde, L. E. (2014), ““Systematic combining” — A decade later”, Journal of Business Research, Vol. 67, No. 6, pp. 1277-1284.

Duncan, R.B. (1972), "Characteristics of organizational environments and perceived environmental uncertainty”, Administrative Science Quarterly, Vol. 17 No. 3, pp. 313-327.

Eisenhardt, K. M. (1989), "Building theories from case study research", Academy of Management Review, Vol. 14, No. 4, pp. 532-550.

Eisenhardt, K.M. and Graebner, M.E. (2007), 'Theory building from cases: Opportunities and challenges", Academy of Management Journal, Vol. 50, No. 1, pp. 25-32.

Ellram, L.M., Zsidisin, G.A., Siferd, S.P. and Stanly, M.J. (2002), "The impact of purchasing and supply management activities on corporate success", Journal of Supply Chain Management, Vol. 38 No. 4, pp. 4-17.

European Commission (2019), The Digital Economy and Society Index (DESI) 2019, available at: https://ec.europa.eu/digital-single-market/en/desi.

Faes, W., Matthyssens, P. and Vandenbempt, K. (2000), ’The pursuit of global purchasing synergy", Industrial Marketing Management, Vol. 29, No. 6, pp. 539-553.

Foerstl, K., Meinlschmidt, J. and Busse, C. (2018), "It's a match! Choosing information processing mechanisms to address sustainability-related uncertainty in sustainable supply management", Journal of Purchasing and Supply Management, Vol. 24, No. 3, pp. 204-217.

Fung, H. (2014), Criteria, use cases and effects of information technology process automation $($ ITPA). $<$ https://papers.ssrn.com/sol3/papers.cfm?abstract_id=2588999>

Galbraith, J.R. (1977), Organization Design. Addison Wesley Publishing Company.

Gary, M.S. and Wood, R.E. (2011), "Mental models, decision rules, and performance heterogeneity", Strategic Management Journal, Vol. 32, No. 6, pp. 569-594.

Gibbert, M., Ruigrok, W. and Wicki, B. (2008), "What passes as a rigorous case study?", Strategic Management Journal, Vol. 29, No. 13, pp. 1465-1474.

Gibson, C. B., Dunlop, P. D. and Cordery, J. L. (2019), "Managing formalization to increase global team effectiveness and meaningfulness of work in multinational organizations", Journal of International Business Studies, Vol. 50, No. 6, pp. 1021-1052. 
Goodhue, D. L. and Thompson, R. L. (1995), "Task-technology fit and individual performance", MIS Quarterly, Vol. 19, No. 2, pp. 213-236.

Gray, J. and Prud'homme, A. (2019), “Tracking technology for your organization”, Inside Supply Management, May, pp. 34-35.

Gualandris, J., Legenvre, H. and Kalchschmidt, M. (2018), "Exploration and exploitation within supply networks: Examining purchasing ambidexterity and its multiple performance implications", International Journal of Operations \& Production Management, Vol. 38, No. 3, pp. 667-689.

Handfield, R., Jeong, S. and Choi, T. (2019), "Emerging procurement technology: Data analytics and cognitive analytics", International Journal of Physical Distribution \& Logistics Management, Vol. 49 No. 10, pp. 972-1002.

Hartmann, E., Kerkfeld, D. and Henke, M. (2012), "Top and bottom line relevance of purchasing and supply management", Journal of Purchasing and Supply Management, Vol. 18 , No. 1, pp. 22-34.

Huber, G. P. (1990), "A theory of the effects of advanced information technologies on organizational design, intelligence, and decision making", Academy of Management Review, Vol. 15, No. 1, pp. 47-71.

Johnson, P. F., Klassen, R. D., Leenders, M. R. and Awaysheh, A. (2007), ’Utilizing ebusiness technologies in supply chains: the impact of firm characteristics and teams", Journal of Operations Management, Vol. 25, No. 6, pp. 1255-1274.

Karjalainen, K. and Van Raaij, E. M. (2011), ”An empirical test of contributing factors to different forms of maverick buying", Journal of Purchasing and Supply Management, Vol. 17, No. 3, pp. 185-197.

Kauppi, K. and Van Raaij, E. M. (2015), ”Opportunism and honest incompetence - seeking explanations for noncompliance in public procurement", Journal of Public Administration Research and Theory, Vol. 25, No. 3, pp. 953-979.

Kilpi, V., Lorentz, H., Solakivi, T. and Malmsten, J. (2018), ’The effect of external supply knowledge acquisition, development activities and organizational status on the supply performance of SMEs", Journal of Purchasing and Supply Management, Vol. 24, No. 3, pp. 247-259.

Kogut, B. and Zander, U. (1992), "Knowledge of the firm, combinative capabilities, and the replication of technology”, Organization Science, Vol. 3, No. 3, pp. 383-397.

Kosmol, T., Reimann, F. and Kaufmann, L. (2019), "You'll never walk alone: Why we need a supply chain practice view on digital procurement", Journal of Purchasing and Supply Management, Vol. 25, No. 4, p. 100553.

Kumar, K. and van Dissel, H. G. (1996), "Sustainable collaboration: managing conflict and cooperation in interorganizational systems", MIS Quarterly, pp. 279-300. 
Liu, H., Ke, W., Wei, K.K., Gu, J. and Chen, H. (2010), "The role of institutional pressures and organizational culture in the firm's intention to adopt internet-enabled supply chain management systems", Journal of Operations Management, Vol. 28 No. 5, pp. 372-384.

Lorentz, H., Laari, S., Engblom, J. and Tanskanen, K. (2019), ”Attention-based view on achieving ambidexterity in purchasing and supply management", Journal of Purchasing and Supply Management, Vol. 25, No. 5, 100560.

Luthans, F. and Stewart, T.I. (1977), "A general contingency theory of management", Academy of Management Review, Vol. 2 No. 2, pp. 181-195.

Miles, M.B. and Huberman, A.M. (1994), Qualitative Data Analysis: An Expanded Sourcebook, SAGE.

Morecroft, J.D. (1992), “Executive knowledge, models and learning”, European Journal of Operational Research, Vol. 59 No. 1, pp. 9-27.

Nadal, S., Romero, O., Abelló, A., Vassiliadis, P. and Vansummeren, S. (2019), “An integration-oriented ontology to govern evolution in big data ecosystems", Information Systems, Vol. 79, 3-19.

Nonaka, I. (1994), “A dynamic theory of organizational knowledge creation”, Organization Science, Vol. 5, No. 1, pp 14-37.

Patton, M.Q. (2002), Qualitative Research \& Evaluation Methods, SAGE, Thousand Oaks.

Porac, J. F. and Thomas, H. (1990), “Taxonomic mental models in competitor definition”, Academy of Management Review, Vol. 15, No. 2, pp. 224-240.

Presutti, W. D. (2003), "Supply management and e-procurement: creating value added in the supply chain”, Industrial Marketing Management, Vol. 32, No. 3, pp. 219-226.

Purchase, S. and Dooley, K. (2010), "The acceptance and use of e-procurement systems", International Journal of Logistics: Research and Applications, Vol. 13, No. 6, pp. 459-473.

Rogers, E. M. (2010), Diffusion of Innovations. The Free Press, Simon and Schuster Inc., New York.

Ronchi, S., Brun, A., Golini, R. and Fan, X. (2010), "What is the value of an IT eprocurement system? Journal of Purchasing and Supply Management, Vol. 16, No. 2, pp. 131-140.

Rozemeijer, F. (2000), "How to manage corporate purchasing synergy in a decentralised company? Towards design rules for managing and organising purchasing synergy in decentralised companies", European Journal of Purchasing \& Supply Management, Vol. 6, No. 1, pp. 5-12.

Saccani, N. and Perona, M. (2007), "Shaping buyer-supplier relationships in manufacturing contexts: Design and test of a contingency model", Journal of Purchasing and Supply Management, Vol. 13, No. 1, pp. 26-41. 
Sanders, N.R. (2016), "How to use big data to drive your supply chain", California Management Review, Vol. 58 No. 3, pp. 26-48.

Shook, C.L., Adams, G.L., Ketchen Jr, D.J. and Craighead, C.W. (2009), “Towards a "theoretical toolbox" for strategic sourcing", Supply Chain Management: an International Journal, Vol. 14, No. 1, pp. 3-10.

Simon, H.A. (2019), The Sciences of the Artificial, MIT press.

Smart, A. (2010), "Exploring the business case for e-procurement", International Journal of Physical Distribution \& Logistics Management.

Smart, A. and Dudas, A. (2007), "Developing a decision-making framework for implementing purchasing synergy: a case study", International Journal of Physical Distribution \& Logistics Management.

Soares-Aguiar, A. and Palma-dos-Reis, A. (2008), "Why do firms adopt e-procurement systems? Using logistic regression to empirically test a conceptual model", IEEE Transactions on Engineering Management, Vol. 55, No. 1, pp. 120-133.

Spina, G., Caniato, F., Luzzini, D., \& Ronchi, S. (2016), “Assessing the use of external grand theories in purchasing and supply management research", Journal of Purchasing and Supply Management, Vol. 22, No. 1, pp. 18-30.

Säfsten, K., Winroth, M. and Stahre, J. (2007), “The content and process of automation strategies", International Journal of Production Economics, Vol. 110, No. 1-2, pp. 25-38.

Søgaard, B., Skipworth, H.D., Bourlakis, M., Mena, C. and Wilding, R. (2019), "Facing disruptive technologies: Aligning purchasing maturity to contingencies", Supply Chain Management: An International Journal, Vol. 24 No. 1, pp. 147-169.

Sousa, R. and Voss, C.A. (2008), "Contingency research in operations management practices”, Journal of Operations Management, Vol. 26 No. 6, pp. 697-713.

Srai, J. S. and Lorentz, H. (2019), "Developing design principles for the digitalization of purchasing and supply management", Journal of Purchasing and Supply Management, Vol. 25 No. 1, pp. 78-98.

Tatsis, V., Mena, C., Van Wassenhove, L. N. and Whicker, L. (2006), "E-procurement in the Greek food and drink industry: drivers and impediments", Journal of Purchasing and Supply Management, Vol. 12, No. 2, pp. 63-74.

Teo, T. S., Lin, S. and Lai, K. H. (2009), “Adopters and non-adopters of e-procurement in Singapore: An empirical study”, Omega, Vol. 37, No. 5, pp. 972-987.

Thompson, J. D. (1967), Organizations in Action, McGraw-Hill. New York. 
Toktaş-Palut, P., Baylav, E., Teoman, S. and Altunbey, M. (2014), "The impact of barriers and benefits of e-procurement on its adoption decision: An empirical analysis", International Journal of Production Economics, Vol. 158, pp. 77-90.

Tushman, M. L. and Nadler, D. A. (1978), "Information processing as an integrating concept in organizational design", Academy of Management Review, Vol. 3, No. 3, pp. 613-624.

van den Broek, T. and van Veenstra, A. F. (2018), "Governance of big data collaborations: How to balance regulatory compliance and disruptive innovation", Technological Forecasting and Social Change, Vol. 129, 330-338.

van Weele, A. J. and van Raaij, E. M. (2014), "The future of purchasing and supply management research: About relevance and rigor", Journal of Supply Chain Management, Vol. 50, No. 1, pp. 56-72.

Waddock, S. A., Bodwell, C. and Graves, S. B. (2002), "Responsibility: The new business imperative", Academy of Management Perspectives, Vol. 16, No. 2, 132-148.

Walker, H. and Harland, C. (2008), "E-procurement in the United Nations: Influences, issues and impact", International Journal of Operations \& Production Management, Vol. 28, No. 9, pp. 831-857.

Waller, M. A. and Fawcett, S. E. (2013), "Data science, predictive analytics, and big data: a revolution that will transform supply chain design and management", Journal of Business Logistics, Vol. 34, No. 2, pp. 77-84.

Williamson, O.E., (1981), "The economics of organization: The transaction cost approach," The American Journal of Sociology, Vol. 87, No. 3, pp. 548-577.

Wu, F., Zsidisin, G. and Ross, A. (2007), "Antecedents and outcomes of e-procurement adoption: an integrative model”, IEEE Transactions on Engineering Management, Vol. 54, No. 3, pp. 576-587.

Yin, R.K. (2009), Case Study Research: Design and Methods. Sage, Thousand Oaks, CA.

Zhu, Q., Sarkis, J. and Lai, K.H. (2013), "Institutional-based antecedents and performance outcomes of internal and external green supply chain management practices", Journal of Purchasing and Supply Management, Vol. 19, No. 2, pp. 106-117.

Zigurs, I. and Buckland, B. K. (1998), "A theory of task/technology fit and group support systems effectiveness”, MIS Quarterly, pp. 313-334.

Zsidisin, G.A., Hartley, J.L., Bernardes, E.S. and Saunders, L.W. (2015), "Examining supply market scanning and internal communication climate as facilitators of supply chain integration”, Supply Chain Management: An International Journal, Vol. 20 No. 5, pp. 549560 .

Zsidisin, G.A., Melnyk, S.A. and Ragatz, G.L. (2005), “An institutional theory perspective of business continuity planning for purchasing and supply management", International Journal of Production Research, Vol. 43, No. 16, pp. 3401-3420. 
Page 27 of 47

International Journal of Operations and Production Management

$$
1
$$

2

3

4

5

6

7

8

9

10

11

12

13

14

15

16

17

18

19

20

21

22

23

24

25

26

27

28

29

30

31

32

33

34

35

36

37

38

39

40

41

42

43

44

45

46

47

48

49

50

51

52

53

54

55

56

57

58

59

60

27 


\section{APPENDIX A: Interview guide}

1. What are your key priorities and challenges for procurement at the moment?

2. What kind status does procurement have? Does it have representation in the top management team? How does collaboration with other functions work?

3. Why is procurement digitalization a relevant topic for you? What are your aims regarding procurement digitalization? Do you have a digital/digitalization strategy?

4. What kind of digital applications do you a) have in use, b) have decided to implement, c) plan to implement in the next 2-10 years? Please position the application in the grid [see Srai and Lorentz, 2019].

5. For each application:

a. What kind of application is this? Powering technologies? Functionalities? [intervention]

b. What do you aim for with the application? Observed or assumed capability and performance implications? [mechanism]

c. Why was/will the application be implemented? Which phenomenon, problem, challenge, requirement or pressure led to planning or implementation?

[context] 


\begin{tabular}{|c|c|c|c|c|}
\hline \multicolumn{5}{|c|}{ Appendix B Reduced form data of the case study } \\
\hline UoA & Case & Context & Intervention & Mechanism \\
\hline 1 & Chemicals & $\begin{array}{l}\text { Internal complexity: global business and the need to } \\
\text { harmonize procurement, integrated system for } \\
\text { replacing separate legacy systems, prohibiting } \\
\text { information flow }\end{array}$ & $\begin{array}{l}\text { Process structuring: cloud-based integrated system for } \\
\text { managing sourcing, buying, invoicing, contracts and suppliers } \\
\text { through a portal; }\end{array}$ & $\begin{array}{l}\text { Coordination and control: better use of contract } \\
\text { terms, leveraging sourcing achievements, control of } \\
\text { buying through accepted requisitions, ease-of-use as } \\
\text { priority improving acceptance }\end{array}$ \\
\hline 2 & Chemicals & $\begin{array}{l}\text { External dynamism / internal complexity: multiple } \\
\text { dynamic supply markets for indirect procurement to } \\
\text { manage; } \\
\text { Normative pressure: data as a key asset in } \\
\text { procurement, drive for digitalisation and using supply } \\
\text { market intelligence; } \\
\text { Coercive pressure: regulatory requirements for data } \\
\end{array}$ & $\begin{array}{l}\text { Information processing: Power BI reports with data from } \\
\text { different sources, self-service portal for accessing market } \\
\text { data, raw material prices, country risk indicators, supplier } \\
\text { financials etc. } \\
\end{array}$ & $\begin{array}{l}\text { Supply market knowledge: aim for efficiency in } \\
\text { accessing supply market intelligence, ability to deal } \\
\text { with and respond to new compliance requirements }\end{array}$ \\
\hline 3 & Chemicals & $\begin{array}{l}\text { External complexity: dozens of contractors involved } \\
\text { in regular operations and large scale facility } \\
\text { maintenance projects, legacy process highly manual } \\
\text { with large volume of tasks }\end{array}$ & $\begin{array}{l}\text { Process structuring: cloud-based system for external } \\
\text { contractors to report their work on facility maintenance, } \\
\text { integrated with ERP and acceptance systems; }\end{array}$ & $\begin{array}{l}\text { Coordination and control: more efficient linking of } \\
\text { work reports with contracts and the associated terms, } \\
\text { provides transparency into the process }\end{array}$ \\
\hline 4 & Energy & $\begin{array}{l}\text { Choice for savings and efficiency: savings, task } \\
\text { simplification and support }\end{array}$ & $\begin{array}{l}\text { Process structuring: RPA applied to purchase-to-pay } \\
\text { process and supplier management }\end{array}$ & Process improvement: automation \\
\hline 5 & Energy & Internal complexity: global multiunit organisation & Information processing: spend analytics solutions & $\begin{array}{l}\text { Coordination and control: global view to spend, } \\
\text { harmonization and consolidation }\end{array}$ \\
\hline 8 & Food & $\begin{array}{l}\text { Internal complexity: Need to control and coordinate } \\
\text { multiunit and dispersed procurement organisation }\end{array}$ & $\begin{array}{l}\text { Process structuring: (improved, more flexible and easier for } \\
\text { suppliers) e-catalogues }\end{array}$ & $\begin{array}{l}\text { Coordination and control: Reduction of maverick } \\
\text { buying }\end{array}$ \\
\hline 9 & Food & $\begin{array}{l}\text { Choice for sustainability: Organic and local supply } \\
\text { key priorities for the firm }\end{array}$ & $\begin{array}{l}\text { Communication support: Social media and other mobile } \\
\text { apps }\end{array}$ & $\begin{array}{l}\text { Strategic alignment for sustainability: Visibility } \\
\text { into the source for the company and consumers }\end{array}$ \\
\hline 10 & HeavyMach & \begin{tabular}{|l|} 
Choice for savings and efficiency: cost \\
competitiveness as a priority, suppliers communicate \\
with emails, need to input delivery data into ERP \\
systems
\end{tabular} & $\begin{array}{l}\text { Process structuring: system integration and automation of } \\
\text { small and repetitive tasks, RFQ automation }\end{array}$ & $\begin{array}{l}\text { Transaction management; process improvement: } \\
\text { automation }\end{array}$ \\
\hline 11 & HeavyMach & $\begin{array}{l}\text { Choice for reliability: supply chain transparency as a } \\
\text { driver }\end{array}$ & $\begin{array}{l}\text { Information processing: IoT and mobile technologies } \\
\text { connected to Supplier web }\end{array}$ & $\begin{array}{l}\text { Supplier capability assessment: inbound order } \\
\text { tracking }\end{array}$ \\
\hline 12 & HeavyMach & $\begin{array}{l}\text { External dynamism: volatile commodity prices and } \\
\text { recent investments in reporting and analytics } \\
\text { capabilities }\end{array}$ & $\begin{array}{l}\text { Information processing: RPA for commodity price } \\
\text { collection }\end{array}$ & $\begin{array}{l}\text { Supply market knowledge: enhanced supply market } \\
\text { intelligence }\end{array}$ \\
\hline
\end{tabular}




\begin{tabular}{|c|c|c|c|c|}
\hline 13 & HeavyMach & $\begin{array}{l}\text { External complexity: high number of suppliers, } \\
\text { availability challenge, transparency as a driver }\end{array}$ & $\begin{array}{l}\text { Information processing: risk analysis application (cloud } \\
\text { based, follows news feed) }\end{array}$ & Supply market knowledge \\
\hline 14 & HeavyMach & $\begin{array}{l}\text { External complexity: global business and supply } \\
\text { base }\end{array}$ & $\begin{array}{l}\text { Communication support: virtual supplier development } \\
\text { engineer -app for supporting suppliers in problem solving }\end{array}$ & $\begin{array}{l}\text { Relationship management; Process improvement } \\
\text { due to less travel }\end{array}$ \\
\hline 15 & HeavyMach & $\begin{array}{l}\text { Choice for agility and speed: aim for transparency } \\
\text { and speed in the supply chain }\end{array}$ & $\begin{array}{l}\text { Communication support: supplier portal for communicating } \\
\text { transport (with IoT \& mobile tech.), drawings, quality } \\
\text { notifications and performance }\end{array}$ & $\begin{array}{l}\text { Relationship management: collaboration and } \\
\text { transparency }\end{array}$ \\
\hline 16 & Instruments & $\begin{array}{l}\text { External dynamism: visibility cross-functionally and } \\
\text { in supplier relationships as a priority due to demand } \\
\text { fluctuation }\end{array}$ & $\begin{array}{l}\text { Communication support: supplier web, also with mobile } \\
\text { access }\end{array}$ & $\begin{array}{l}\text { Process improvement; Relationship management: } \\
\text { sharing of forecast with suppliers, visibility into } \\
\text { inventories (inventory reduction) }\end{array}$ \\
\hline 17 & Instruments & $\begin{array}{l}\text { Choice for savings and efficiency: efficiency and } \\
\text { automation as drivers in procurement excellence } \\
\text { development }\end{array}$ & $\begin{array}{l}\text { Process structuring: application of RPA to manual buying } \\
\text { and sourcing work. Automation of component data input } \\
\text { (integration of systems with RPA) }\end{array}$ & $\begin{array}{l}\text { Process improvement: make the work of sourcing } \\
\text { managers easier (less burden) }\end{array}$ \\
\hline 18 & Instruments & $\begin{array}{l}\text { Choice for innovation: innovation focused company. } \\
\text { Procurement seeks to bring in technologies and } \\
\text { innovation from supply base, ESI }\end{array}$ & $\begin{array}{l}\text { Information processing: cloud-based Supplier Collaboration } \\
\text {-platform for sharing of product data and product change data } \\
\text { with suppliers. Receiving engineering change proposals from } \\
\text { suppliers. }\end{array}$ & $\begin{array}{l}\text { Relationship management: supplier involvement in } \\
\text { product development; } \\
\text { Process improvement: contributes to productivity }\end{array}$ \\
\hline 19 & Instruments & $\begin{array}{l}\text { External dynamism: Long component lead times, } \\
\text { availability and supply risk management challenge }\end{array}$ & $\begin{array}{l}\text { Decision aiding: AI and algorithms applied on historical on- } \\
\text { time-delivery data }\end{array}$ & $\begin{array}{l}\text { Supplier capability assessment: predicting supplier } \\
\text { on-time-delivery and inbound delivery risk } \\
\text { management }\end{array}$ \\
\hline 20 & Instruments & Coercive pressure: REACH regulation & $\begin{array}{l}\text { Information processing: cloud-based system for } \\
\text { examination of suppliers' compliance with the REACH } \\
\text { regulation regarding their products and components. }\end{array}$ & $\begin{array}{l}\text { Strategic alignment: regulatory compliance; } \\
\text { Supplier capability assessment }\end{array}$ \\
\hline 21 & Logistics & $\begin{array}{l}\text { Choice for savings and efficiency: rationalisation of } \\
\text { work; } \\
\text { Choice for agility and speed: faster service of } \\
\text { suppliers and stakeholders; } \\
\text { Internal complexity: challenge of serving the large } \\
\text { multi-unit organisation }\end{array}$ & $\begin{array}{l}\text { Process structuring: SaaS-based platform [Jaggaer] for } \\
\text { managing sourcing projects, incl. supplier onboarding and } \\
\text { management, tendering, RfX, e-auctions, savings registering } \\
\text { (S2C) }\end{array}$ & $\begin{array}{l}\text { Process improvement: accessible single site for all } \\
\text { sourcing related information and tasks (reduction of } \\
\text { multiple data input requirements), simpler process } \\
\text { indepedent of individuals; } \\
\text { Strategic alignment: facilitates project collaboration } \\
\text { with stakeholders }\end{array}$ \\
\hline 22 & Logistics & $\begin{array}{l}\text { Internal complexity: several signatures needed in } \\
\text { sourcing projects }\end{array}$ & $\begin{array}{l}\text { Process structuring: electronic signature application by } \\
\text { Adobe }\end{array}$ & Process improvement: cuts lead time significantly \\
\hline 23 & Logistics & $\begin{array}{l}\text { Obsolescence of old system, with poor user } \\
\text { acceptance }\end{array}$ & $\begin{array}{l}\text { Information processing: external service provider's AI } \\
\text { application processes contract documents by collecting and } \\
\text { categorising content in order to support search and queries }\end{array}$ & $\begin{array}{l}\text { Process improvement: less mistakes, faster, not } \\
\text { dependent on individuals completing tasks; } \\
\text { Coordination \& control: contracts more broadly } \\
\text { accessible and better managed; } \\
\text { Supplier capability assessment: facilitates supplier } \\
\text { assessment and KPIs }\end{array}$ \\
\hline 24 & Logistics & $\begin{array}{l}\text { External coercive pressure: supplier data bases must } \\
\text { meet GDPR regulations }\end{array}$ & $\begin{array}{l}\text { Information processing: RPA solution for deleting data of } \\
\text { unused suppliers from the sourcing portal }\end{array}$ & $\begin{array}{l}\text { Process improvement / relationships management: } \\
\text { more appropriate, up-to-date and compliant supply } \\
\text { base management }\end{array}$ \\
\hline
\end{tabular}




\begin{tabular}{|c|c|c|c|c|}
\hline 25 & Logistics & $\begin{array}{l}\text { External complexity: many supply markets for } \\
\text { heterogeneous spend, many suppliers and of different } \\
\text { types }\end{array}$ & $\begin{array}{l}\text { Information processing: data warehouse and Power BI } \\
\text { application with spend data, internal supplier status data, } \\
\text { external supplier financial data; } \\
\text { Decision aiding: plans for AI based prescriptive analytics for } \\
\text { aiding sourcing managers }\end{array}$ & $\begin{array}{l}\text { Supplier capability assessment: supplier risk profiles } \\
\text { and selection }\end{array}$ \\
\hline 26 & MovingMach & $\begin{array}{l}\text { Choice for savings and efficiency: drive for efficient } \\
\text { procurement operations }\end{array}$ & Process structuring: RPA for invoice handling & $\begin{array}{l}\text { Process improvement: less resources used for } \\
\text { invoide handling (automation), more time for strategic } \\
\text { sourcing }\end{array}$ \\
\hline 27 & MovingMach & Choice for agility and speed: faster time-to-market & Process structuring: AI-based contract benchmarking & $\begin{array}{l}\text { Process improvement: better \& faster contract } \\
\text { formulation and negotiatio; } \\
\text { Strategic alignment: shorter contract cycles and } \\
\text { velocity }\end{array}$ \\
\hline 29 & Pharma & $\begin{array}{l}\text { Internal complexity: Aiming for a common way of } \\
\text { working in all categories---> Today many different } \\
\text { channels and systems }\end{array}$ & $\begin{array}{l}\text { Communication support: Yammer for informing e.g. about } \\
\text { systems updates etc.; Information processing: Sharepoint, } \\
\text { Pallas document management system (incl. contracts and } \\
\text { important data) }\end{array}$ & $\begin{array}{l}\text { Coordination and control: Transparency and } \\
\text { visibility into procurement documents and contracts }\end{array}$ \\
\hline 30 & Pharma & $\begin{array}{l}\text { Choice for savings and efficiency: seeking to } \\
\text { decrease manual work, towards automation }\end{array}$ & Process structuring: automation of tasks in SAP & Process improvement: efficiency, automation \\
\hline 31 & Pharma & $\begin{array}{l}\text { External dynamism: Supplier management } \\
\text { development as a priority, changing supply base } \\
\text { (mergers, production transfers, PLC ramp-downs) }\end{array}$ & $\begin{array}{l}\text { Process structuring: SRM, tendering; Information } \\
\text { processing: cloud-based Polaris-system for supplier } \\
\text { performance measurement (SAS for performance analytics), } \\
\text { contract archive }\end{array}$ & $\begin{array}{l}\text { Coordination and control: achieving a helicopter- } \\
\text { view; Supplier capability assessment: more time for } \\
\text { supplier development }\end{array}$ \\
\hline 33 & Pharma & $\begin{array}{l}\text { Coercive pressure: regulation for traceability and } \\
\text { security in pharma supply chain }\end{array}$ & $\begin{array}{l}\text { Information processing: Big Data and analytics for tracing } \\
\text { raw material origin }\end{array}$ & Strategic alignment: traceability of pharma products \\
\hline 34 & Public & $\begin{array}{l}\text { Internal complexity: customer centric centralised } \\
\text { public procurement unit dealing with complex } \\
\text { organisation, heterogenous spend and supply base; } \\
\text { Choice for agility and speed: with internal customer } \\
\text { service as a priority }\end{array}$ & $\begin{array}{l}\text { Process structuring: Cloud-based platform for supporting } \\
\text { sourcing, contracting, supplier management and category } \\
\text { management processes, as well as stakeholder delegated } \\
\text { buying. }\end{array}$ & $\begin{array}{l}\text { Process improvement: reduction of procurement } \\
\text { process lead time from } 11 \text { months to } 6 \text { months; } \\
\text { Strategic alignment for internal customer service: } \\
\text { reduction of dependency on individuals leading to } \\
\text { reliable and consistent service }\end{array}$ \\
\hline 35 & Public & $\begin{array}{l}\text { Internal complexity: several separate systems and } \\
\text { many workflows }\end{array}$ & $\begin{array}{l}\text { Process structuring: RPA for automating manual tasks and } \\
\text { processes which require data transfer between different } \\
\text { information systems and platforms (systems integration) }\end{array}$ & $\begin{array}{l}\text { Process improvement: better use of procurement } \\
\text { personnel resources with focus on "the beef" }\end{array}$ \\
\hline 36 & Public & $\begin{array}{l}\text { External dynamism: strategy promotes using } \\
\text { functioning markets while market consolidation and } \\
\text { change makes this difficult; } \\
\text { Coercive pressure: public organisations need to } \\
\text { source responsibly, requiring background checks of } \\
\text { supplier key personnel }\end{array}$ & $\begin{array}{l}\text { Information processing: collection and integration of data } \\
\text { from various sources, incl. external service provider data } \\
\text { bases and dispersed district courts around the country }\end{array}$ & $\begin{array}{l}\text { Strategic alignment for compliance: ability to better } \\
\text { meet strategic imperatives and compliance with } \\
\text { regulation and public expectations }\end{array}$ \\
\hline
\end{tabular}




\begin{tabular}{|c|c|c|c|c|}
\hline 37 & Retail 1 & $\begin{array}{l}\text { Strategic choice for differentiation: supply in retail } \\
\text { stores needs to fit with local demands }\end{array}$ & $\begin{array}{l}\text { Decision aiding: AI-based forecasting of product demand in } \\
\text { retail stores }\end{array}$ & $\begin{array}{l}\text { Strategic alignment: supporting strategy through } \\
\text { matching local demands with supply }\end{array}$ \\
\hline 38 & Retail 1 & $\begin{array}{l}\text { External coercive pressure: regulation on making } \\
\text { product information available to consumers in e- } \\
\text { commerce; } \\
\text { Strategic choice for transparency: desire to support } \\
\text { to consumers varying dietary requirements }\end{array}$ & $\begin{array}{l}\text { Information processing: collection and input of suppliers' } \\
\text { product information automatically by deploying RPA }\end{array}$ & $\begin{array}{l}\text { Process improvement; } \text { strategic alignment: } \\
\text { supporting strategy for transparency in e-commerce }\end{array}$ \\
\hline 39 & Retail 1 & $\begin{array}{l}\text { External complexity: need to collaborate with a } \\
\text { large supply base; } \\
\text { Coersive pressure: suppliers expect advanced } \\
\text { systems in order to consider buyer as preferred } \\
\text { customer }\end{array}$ & $\begin{array}{l}\text { Process structuring: SaaS platform for collaboration with } \\
\text { suppliers e.g. in terms of forecasts, information exchange, } \\
\text { bidding, sourcing and contracting, logistics management }\end{array}$ & $\begin{array}{l}\text { Process improvement: more efficient way of } \\
\text { working (automation, less emails), redirecting } \\
\text { resources for more productive tasks; } \\
\text { Relationship management: two-way collaboration }\end{array}$ \\
\hline 40 & Retail 2 & $\begin{array}{l}\text { Internal complexity: Many near-obsolete and siloed } \\
\text { ERP systems in multi-unit organisation }\end{array}$ & $\begin{array}{l}\text { Process structuring: adoption of single ERP across business } \\
\text { units }\end{array}$ & $\begin{array}{l}\text { Process improvement: automation, less mistakes, } \\
\text { efficiency; } \\
\text { Coordination and control: harmonisation; }\end{array}$ \\
\hline 41 & Retail 2 & $\begin{array}{l}\text { Choice for savings and efficiency: effort to secure } \\
\text { and retain savings }\end{array}$ & $\begin{array}{l}\text { Information processing: new spend management application } \\
\text { with use of contract and order data for forward looking } \\
\text { planning in indirect categories; } \\
\text { Decision aiding: predictive analytics }\end{array}$ & $\begin{array}{l}\text { Coordination and control: better steering and } \\
\text { transparency; } \\
\text { Strategic alignment for savings: aim for cost savings }\end{array}$ \\
\hline 42 & Retail 2 & $\begin{array}{l}\text { Internal complexity: many stakeholders and buyers } \\
\text { in indirect; } \\
\text { Obsolesence of old system }\end{array}$ & $\begin{array}{l}\text { Process structuring: Coupa -integrated platform for } \\
\text { supporting new easy-to-use O2P and S2C processes; RPA for } \\
\text { automating e.g. supplier validation and requisitions; } \\
\text { Communication support: Workplace application for } \\
\text { communicating about the system, chatbot for guiding users } \\
\text { chatbot for guiding users } \\
\text { Decision aiding: Workplace application for facilitating } \\
\text { supplier evaluations }\end{array}$ & $\begin{array}{l}\text { Process improvement: renewed S2C process, goal to } \\
\text { achieve } 80 \% \text { automation level for savings; } \\
\text { Coordination and control: steering stakeholders to } \\
\text { behave in a desired way (compliance) } \\
\text { Supplier capability assessment: based on rankings } \\
\text { by other users }\end{array}$ \\
\hline 43 & Retail 2 & $\begin{array}{l}\text { Choice for sustainability: consumer preference for } \\
\text { understanding source of food by tracing }\end{array}$ & $\begin{array}{l}\text { Information processing: blockchain solution for making the } \\
\text { source or domestic fish transparent for the consumer, based } \\
\text { on the IBM Food Trust platform (easy to use interface for } \\
\text { supplier data input). }\end{array}$ & $\begin{array}{l}\text { Strategic alignment for tracing; Process } \\
\text { improvement: optimisation of food supply chain for } \\
\text { less waste and recalls }\end{array}$ \\
\hline 44 & Tele & Choice for savings and efficiency & Process structuring: RPA in contract implementation & Process improvement: automation \\
\hline 45 & Tele & $\begin{array}{l}\text { Internal complexity: aim to make-buying-easy -aim } \\
\text { leads to automatisation and tools }\end{array}$ & Process structuring: buying tools for $b 2 b$ transactions & $\begin{array}{l}\text { Transaction management; Process improvement: } \\
\text { more time for other more important (strategic) tasks }\end{array}$ \\
\hline 46 & Tele & Normative pressure: quest for sourcing excellence & $\begin{array}{l}\text { Process structuring: Ivalua platform, with Clickview; } \\
\text { Information processing: SAP Business Warehouse, Azure } \\
\text { data lake }\end{array}$ & $\begin{array}{l}\text { Strategic alignment; Process improvement: } \\
\text { category management, incl. project pipeline } \\
\text { management, team management }\end{array}$ \\
\hline 47 & Tele & Normative pressure: aim for fact-based procurement & $\begin{array}{l}\text { Decision aiding: supplier performance dashboard drawing on } \\
\text { Big Data analytics, and intelligent anomaly alerts }\end{array}$ & $\begin{array}{l}\text { Supplier capability assessment; Strategic } \\
\text { alignment: data and evidence-based category } \\
\text { management, development and impact assessment }\end{array}$ \\
\hline
\end{tabular}




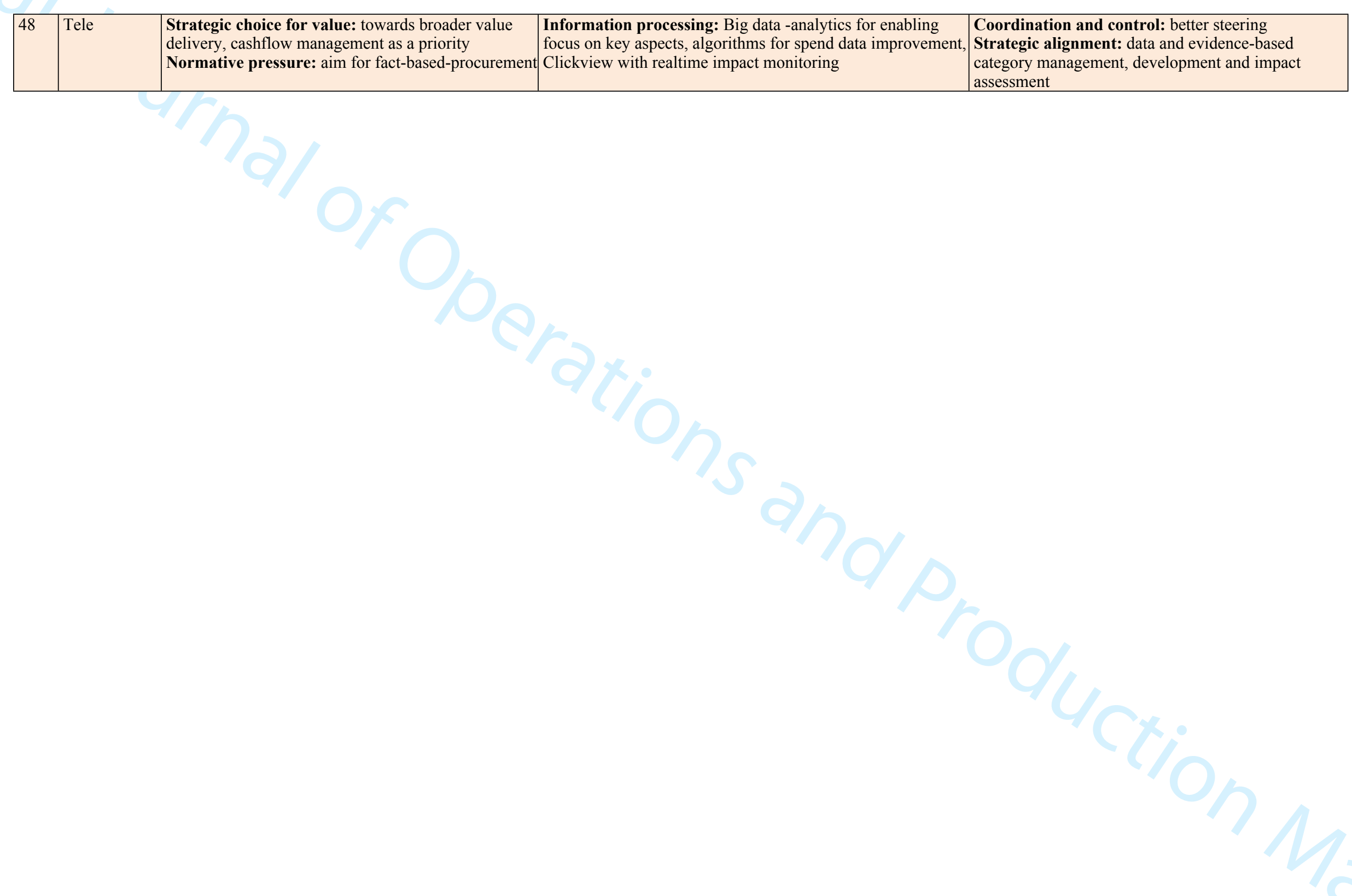


Table I Overview of the cases, and data collection

\begin{tabular}{|c|c|c|c|}
\hline $\begin{array}{l}\text { Case ID and } \\
\text { turnover }\end{array}$ & $\begin{array}{l}\text { Industry/Company } \\
\text { description }\end{array}$ & $\begin{array}{l}\text { UoA } \\
\#\end{array}$ & Data collection details and validation \\
\hline $\begin{array}{l}\text { Chemicals } \\
>10000 \text { MEUR }\end{array}$ & $\begin{array}{l}\text { Oil refinery and } \\
\text { distribution }\end{array}$ & 3 & $\begin{array}{l}\text { Interview ( } 60 \mathrm{~min} \text { ) Manager, Procurement process } \\
\text { development, Development Manager, } 2 \text { researchers }\end{array}$ \\
\hline $\begin{array}{l}\text { Energy } \\
>5000 \text { MEUR }\end{array}$ & $\begin{array}{l}\text { Energy production } \\
\text { and distribution }\end{array}$ & 3 & $\begin{array}{l}\text { Interview (56 min) with } 1 \text { informant (Head of procurement } \\
\text { development) and } 2 \text { researchers; interactive fill-in of } \\
\text { digitalization grid; data validation workshop } 1 \text { participant. }\end{array}$ \\
\hline $\begin{array}{l}\text { Food } \\
\sim 300 \text { MEUR }\end{array}$ & $\begin{array}{l}\text { Food, Vegetable } \\
\text { based (frozen) food } \\
\text { manufacturer }\end{array}$ & 3 & $\begin{array}{l}\text { Interview (56 } \mathrm{min}) \text { with } 1 \text { informant (Head of procurement } \\
\text { and logistics) and } 2 \text { researchers; interactive fill-in of } \\
\text { digitalization grid; data validation workshop } 1 \text { participant. }\end{array}$ \\
\hline $\begin{array}{l}\text { HeavyMach } \\
>5000 \text { MEUR }\end{array}$ & $\begin{array}{l}\text { Machinery, heavy } \\
\text { machinery building } \\
\text { for marine and } \\
\text { energy sectors }\end{array}$ & 6 & $\begin{array}{l}\text { Interview ( } 77 \mathrm{~min}) \text { with } 2 \text { informants (Director, supply } \\
\text { management, Manager, material supply process) and } 2 \\
\text { researchers; interactive fill-in of digitalization grid; data } \\
\text { validation workshop } 1 \text { participant. }\end{array}$ \\
\hline $\begin{array}{l}\text { Instruments } \\
\sim 350 \text { MEUR }\end{array}$ & $\begin{array}{l}\text { High tech } \\
\text { engineering, } \\
\text { specialized in } \\
\text { measurement } \\
\text { equipment }\end{array}$ & 5 & $\begin{array}{l}\text { Interview (61 min) with } 2 \text { informants (Senior category } \\
\text { manager, Head of strategic sourcing and supply chain) and } 3 \\
\text { researchers; interactive fill-in of digitalization grid; data } \\
\text { validation workshop } 2 \text { participants. }\end{array}$ \\
\hline $\begin{array}{l}\text { Logistics } \\
>300 \text { MEUR }\end{array}$ & $\begin{array}{l}\text { Package and mail } \\
\text { delivery }\end{array}$ & 3 & $\begin{array}{l}\text { Interview (61min) Sourcing Manager } 2 \text { researchers, Interview } \\
\text { (70 min) Development Manager } 3 \text { researchers }\end{array}$ \\
\hline $\begin{array}{l}\text { MovingMach } \\
\sim 1600 \text { MEUR }\end{array}$ & $\begin{array}{l}\text { Machinery, offers } \\
\text { machines for load } \\
\text { handling and } \\
\text { moving }\end{array}$ & 4 & $\begin{array}{l}\text { Interview ( } 70 \mathrm{~min}) \text { with } 2 \text { informants (Manager, indirect } \\
\text { purchases and digitalization, Manager, sourcing competence } \\
\text { development and training) and } 2 \text { researchers; interactive fill-in } \\
\text { of digitalization grid; data validation workshop } 2 \text { participants. }\end{array}$ \\
\hline $\begin{array}{l}\text { Pharma } \\
\sim 1000 \text { MEUR }\end{array}$ & $\begin{array}{l}\text { Pharmaceuticals } \\
\text { production }\end{array}$ & 5 & $\begin{array}{l}\text { Interview ( } 87 \mathrm{~min}) \text { with } 3 \text { informants (Head of indirect } \\
\text { procurement, Sourcing manager, Specialist, process and tools) } \\
\text { and } 3 \text { researchers; interactive fill-in of digitalization grid; data } \\
\text { validation workshop } 2 \text { participants. }\end{array}$ \\
\hline $\begin{array}{l}\text { Public } \\
>2000 \text { MEUR }\end{array}$ & $\begin{array}{l}\text { City, public } \\
\text { organization }\end{array}$ & 3 & $\begin{array}{l}\text { Interview (60min) Sourcing Director and } 2 \text { researchers, } \\
\text { Interview (55min) Development Manager, System Expert and } \\
2 \text { researchers }\end{array}$ \\
\hline $\begin{array}{l}\text { Retail } 1 \\
>5000 \text { MEUR }\end{array}$ & Retailing & 3 & Interview (59 min) Supply Chain Director, 3 researchers \\
\hline $\begin{array}{l}\text { Retail } 2 \\
>5000 \text { MEUR }\end{array}$ & Retailing & 4 & $\begin{array}{l}\text { Interview (53 min), Director of Indirect Procurement, } 3 \\
\text { researchers; interview ( } 49 \mathrm{~min}) \text {, Interview (55min) with } \\
\text { Sustainability Manager, } 1 \text { researcher. }\end{array}$ \\
\hline $\begin{array}{l}\text { Tele } \\
>5000 \text { MEUR }\end{array}$ & $\begin{array}{l}\text { Telecommunication } \\
\text { s, connectivity } \\
\text { solutions }\end{array}$ & 5 & $\begin{array}{l}\text { Interview ( } 55 \mathrm{~min}) \text { with } 1 \text { informant (Head of Strategic } \\
\text { Transformation and Analytics) and } 2 \text { researchers; interactive } \\
\text { fill-in of digitalization grid; workshop } 1 \text { participant. }\end{array}$ \\
\hline
\end{tabular}


Table II Contexts with representative examples from the data

\begin{tabular}{|c|c|c|}
\hline $\begin{array}{l}\text { Context } \\
\text { categories }\end{array}$ & Subcategories & Representative data examples (case acronym) \\
\hline \multirow[t]{4}{*}{$\begin{array}{l}\text { External and } \\
\text { internal } \\
\text { contingencies } \\
\text { (C1) }\end{array}$} & $\begin{array}{l}\text { External } \\
\text { dynamism }\end{array}$ & $\begin{array}{l}\text { Dynamic supply market: e.g. "Typically in low season capacity disappears from supplier } \\
\text { markets, and can't be easily replaced when demand rises. This requires a capability to ensure the } \\
\text { supplier and sub-supplier capability to respond to the demand." (HeavyMach) } \\
\text { High risks in supply market: e.g. "Currently component availability is a challenge, combined } \\
\text { with long lead times." (Instruments) } \\
\text { Volatile prices: e.g. "Naturally due to the market situation, availability is starting to be a } \\
\text { challenge on its own. And this will have an effect on the raw material prices." (MovingMach) } \\
\text { Business dynamism: e.g. "The business cycles are such that it goes high up and sometimes to } \\
\text { the other direction ... cycles have become faster." (HeavyMach) }\end{array}$ \\
\hline & $\begin{array}{l}\text { External } \\
\text { complexity }\end{array}$ & $\begin{array}{l}\text { Supply base complexity: e.g. "We have a large number of suppliers, but managed to reduce the } \\
\text { number of suppliers in last few years. And our world is very complex, we have over } 50000 \\
\text { components and } 6000 \text { products." (Instruments); "We need to know and manage the whole } \\
\text { upstream supply chain, and it is very long chain of actors." (Pharma) }\end{array}$ \\
\hline & $\begin{array}{l}\text { Internal } \\
\text { complexity }\end{array}$ & $\begin{array}{l}\text { Multiunit and dispersed procurement organization: e.g. "We have many business units and } \\
\text { have grown through acquisitions, and as a result there are fragmented ways of operating." } \\
\text { (Energy) "We are a scattered company with independent subsidiaries. We have a challenge to } \\
\text { create and use a uniform company voice when we talk to our big suppliers and not to have } \\
\text { separate discussions in each country." (Tele); } \\
\text { Several separate systems and workflows: e.g. "If you look at for example contract management, } \\
\text { we identified } 42 \text { different workflows, and these are significant workflows." (Public); "Yes this } \\
\text { is about system overhaul of our entire retail business, with SAP having a central role, and a } \\
\text { common system implementation across our retail businesses." (Retail 1) } \\
\text { Many stakeholders: e.g. "... and in the indirect, of } 40000 \text { employees in the business, at } \\
\text { minimum } 8000 \text { individuals buy. And in fact this is the complexity difference." (Retail 2);"...big } \\
\text { challenge is how we serve the relatively sizeable organisation." (Logistics) }\end{array}$ \\
\hline & Other & $\begin{array}{l}\text { e.g. "... we had many systems going sour, and we kind of had to get rid of them, or we have to } \\
\text { get rid of them." (Retail 2) }\end{array}$ \\
\hline \multirow[t]{8}{*}{$\begin{array}{l}\text { Organizations } \\
\text { strategic choice } \\
\text { for } \ldots \text { (C2) }\end{array}$} & $\begin{array}{l}\text { savings and } \\
\text { efficiency }\end{array}$ & $\begin{array}{l}\text { e.g. "The company strategy defines the strategic priorities for PSM, of which the most important } \\
\text { one is improving profitability." (Food); "Well traditionally savings is probably the number one." } \\
\text { (MovingMach); "And another one is then automation, or this kind process efficiency, if we for } \\
\text { example can automate processes." (Tele) }\end{array}$ \\
\hline & speed & $\begin{array}{l}\text { e.g. "One important goal is shortening lead times in procurement, increasing clock speed." } \\
\text { (Pharma); "Other goals [than savings] are agility and speed." (MovingMach) }\end{array}$ \\
\hline & reliability & $\begin{array}{l}\text { e.g. "Reliability is one of our priorities. It means top performance in deliveries and quality." } \\
\text { (Instruments); "Availability is high in our agenda, how to ensure availability." (HeavyMach) }\end{array}$ \\
\hline & sustainability & $\begin{array}{l}\text { e.g. "We must act responsibly, the importance of that has risen a lot. Even that we operate in a } \\
\text { traditional industry the customers require sustainability from us." (Equipment); } \\
\text { "Sustainability is a hot topic for us and a priority". (Pharma) }\end{array}$ \\
\hline & innovation & $\begin{array}{l}\text { e.g. "As we are a technology innovation firm, we must get innovations from the supply base and } \\
\text { involve our suppliers to product development already in early phases." (Instruments) }\end{array}$ \\
\hline & transparency & $\begin{array}{l}\text { e.g. "Transperancy is important for us; that we can give information to suppliers and we know } \\
\text { what they are doing. We need to know the whole upstream supply chain." (Pharma) }\end{array}$ \\
\hline & differentiation & $\begin{array}{l}\text { e.g. "So we of course seek to match our store specific offerings with the consumer base in each } \\
\text { case." (Retail 1) }\end{array}$ \\
\hline & value & $\begin{array}{l}\text { e.g. "So there is "deliver value" as number one. So before him [current CPO], we were very } \\
\text { much a savings machine." (Tele) }\end{array}$ \\
\hline \multirow[t]{2}{*}{$\begin{array}{l}\text { Institutional } \\
\text { pressure }\end{array}$} & $\begin{array}{l}\text { Coercive } \\
\text { pressure }\end{array}$ & $\begin{array}{l}\text { Regulations: e.g. "Compliance is one goal in digitalization, for example data management } \\
\text { needs to meet data privacy requirements." (Energy); "Our business is strictly regulated, and it } \\
\text { defines the risk level: they can't be taken." (Pharma) } \\
\text { Demands from suppliers: e.g. "... so the key issue in the retail business is that suppliers really } \\
\text { expect that retail drives this change." (Retail 1) }\end{array}$ \\
\hline & $\begin{array}{l}\text { Normative } \\
\text { pressure }\end{array}$ & $\begin{array}{l}\text { Aim for fact-based procurement: "... the entire mass of data it is our important asset, and it } \\
\text { should be handled as such." (Chemicals); } \ldots \text { so that we could be an organisation more led with } \\
\text { facts. And not with emotions or gut-feel." (Tele) }\end{array}$ \\
\hline
\end{tabular}


Table III Interventions with representative examples from the data

\begin{tabular}{|c|c|c|}
\hline Intervention category & Subcategory and definition & Representative examples \\
\hline \multirow{2}{*}{$\begin{array}{l}\text { Communication } \\
\text { support: Technologies } \\
\text { that support, enhances } \\
\text { or define the capability } \\
\text { of group members to } \\
\text { communicate with } \\
\text { each other (Zigurs and } \\
\text { Buckland, 1998) }\end{array}$} & $\begin{array}{l}\text { Internal communication } \\
\text { support: Supporting, enhancing, } \\
\text { or defining the capability of the } \\
\text { procurement to communicate } \\
\text { inside procurement and across } \\
\text { functions in an organization. }\end{array}$ & $\begin{array}{l}\text { e.g. "But this has been, from the point of view of our project, our } \\
\text { most important communications channel, kind of like an internal } \\
\text { Facebook." (Retail 2); "... our internal social media, it more } \\
\text { oriented for internal communication of policies." (Energy) }\end{array}$ \\
\hline & $\begin{array}{l}\text { External communication } \\
\text { support: Supporting, enhancing, } \\
\text { or defining the capability to } \\
\text { communicate with external } \\
\text { stakeholders, such as suppliers. }\end{array}$ & $\begin{array}{l}\text { e.g. "we have this supplier web, for this demand supply issue, with } \\
\text { suppliers. So for the operative order-delivery process, and through } \\
\text { this tool we see inventory, and supplier sees the forecast." } \\
\text { (Instruments); "... so through a mobile app you can show a picture, } \\
\text { see here is the bit and the measurement, and then it shows these } \\
\text { virtual reality things and shows that this task here needs to be done } \\
\text { differently." (HeavyMach) }\end{array}$ \\
\hline \multirow[t]{2}{*}{$\begin{array}{l}\text { Process structuring: } \\
\text { Technologies for } \\
\text { supporting, enhancing, } \\
\text { or defining the } \\
\text { processes by which } \\
\text { groups interact (Zigurs } \\
\text { and Buckland, 1998) }\end{array}$} & $\begin{array}{l}\text { Automation oriented process } \\
\text { structuring: } \\
\text { Automating and increasing } \\
\text { efficiency of the processes by } \\
\text { which the procurement function } \\
\text { interacts, drawing on the robotic } \\
\text { process automation technology. }\end{array}$ & $\begin{array}{l}\text { e.g. "... we have used robotic process automation for example for } \\
\text { checking invoices and these kinds of manual tasks." (Public); "In } \\
\text { terms of tools but also for example for robotics, we have a plan, in } \\
\text { order for it to support the entire process." (Energy) }\end{array}$ \\
\hline & $\begin{array}{l}\text { Formalization oriented process } \\
\text { structuring: Formalising and } \\
\text { enhancing procurement processes } \\
\text { by which the procurement } \\
\text { function interacts. }\end{array}$ & $\begin{array}{l}\text { e.g. "... and in the same integrated platform there is the source to } \\
\text { contract -functionality, an in fcat we will renew our way of working } \\
\text { within the source-to-contract process." (Retail 2); } \\
\text { "There is now everything, it is a process-like tool, and you create } \\
\text { projects to which you can attach functionalities, with which I mean } \\
\text { contract management, sourcing, suppliers communication, and } \\
\text { everything related to it." (Logistics); }\end{array}$ \\
\hline \multirow{4}{*}{$\begin{array}{l}\text { Information } \\
\text { processing } \\
\text { technology: } \\
\text { Gathering, sharing, } \\
\text { aggregating, } \\
\text { structuring, or } \\
\text { evaluating information } \\
\text { (Zigurs and Buckland, } \\
\text { 1998) }\end{array}$} & $\begin{array}{l}\text { Internal data integration: } \\
\text { Combining high volume, variety } \\
\text { and velocity data from } \\
\text { heterogeneous internal sources } \\
\text { for improved decision making. }\end{array}$ & $\begin{array}{l}\text { e.g. "... we get new data when we start putting systematically our } \\
\text { contracts to the system, and making buy orders in the system. And } \\
\text { this is in the background, and from it we get actually new data which } \\
\text { we can utilise in the spend analysis process." (Retail } 2 \text { ); "... we have } \\
\text { SAP's Business Warehouse in which we have integrated our } \\
\text { sourcing data. Then we have Clickview on top of it, with which we } \\
\text { present it." (Tele) }\end{array}$ \\
\hline & $\begin{array}{l}\text { External market data } \\
\text { integration } \\
\text { Combining high volume, variety } \\
\text { and velocity of data from } \\
\text { heterogeneous internal and } \\
\text { external sources. }\end{array}$ & $\begin{array}{l}\text { e.g. "... so that we could recognise the risky companies, could we } \\
\text { get weak signals from somewhere? We do a bit of follow up in some } \\
\text { commercial data bases, and we create a lot of reports, but could we } \\
\text { somehow get those signals?" (Public); "... we have different types } \\
\text { of Power BI -reports for which we collect information from various } \\
\text { sources for different needs, as we talked earlier about different } \\
\text { supply market intelligence sources, and we get different kinds of raw } \\
\text { material prices and forecasts." (Chemicals); }\end{array}$ \\
\hline & $\begin{array}{l}\text { External data sharing: Sharing } \\
\text { data with external stakeholders } \\
\text { for a specific purpose. }\end{array}$ & $\begin{array}{l}\text { e.g. "...this supplier collaboration tool or platform, and the first } \\
\text { purpose is the sharing of product data and also changes in product } \\
\text { data." (Instruments) }\end{array}$ \\
\hline & $\begin{array}{l}\text { Data storage and management: } \\
\text { Organising data to ensure access, } \\
\text { quality and use of data. }\end{array}$ & $\begin{array}{l}\text { e.g. “... we got this robot, with which we can delete from our } \\
\text { sourcing portal redundant suppliers, this is the idea.”.(Logistics); ”... } \\
\text { particularly the product information from many small suppliers is a } \\
\text { bit challenging ... there are really manual processes there ... in the } \\
\text { future we will be using robotics in this area." (Retail 1) }\end{array}$ \\
\hline $\begin{array}{l}\text { Decision aiding: } \\
\text { Technologies that } \\
\text { support, inform or } \\
\text { automate procurement } \\
\text { decisions. }\end{array}$ & $\begin{array}{l}\text { Decision aiding tools: } \\
\text { Automating decisions based pre- } \\
\text { defined rules, or evaluating } \\
\text { optional choices based on } \\
\text { gathered relevant information. }\end{array}$ & $\begin{array}{l}\text { e.g. “... information which we did not have in our disposal earlier ... } \\
\text { so this internal customer or ordering data, so we take everything out } \\
\text { of this, and we use it for steering the behaviour of our internal } \\
\text { customers with delegated buying." (Retail 2); ”... the historical data } \\
\text { on OTD is kind of well visible. But the next phase is that we can } \\
\text { forecast what will take place in the future." (Instruments) }\end{array}$ \\
\hline
\end{tabular}


Table IV Mechanism categories and examples from the data

\begin{tabular}{|c|c|}
\hline Mechanism category and definition & Representative examples from cases \\
\hline $\begin{array}{l}\text { Transaction management: efficient } \\
\text { handling of requisition/ procurement-to-pay } \\
\text { processes in the buyer-supplier interface } \\
\text { (Srai and Lorentz, 2019) }\end{array}$ & $\begin{array}{l}\text { e.g. "Well we have process measures and we look at those. For } \\
\text { example, a bit traditional, but this kind of automatching of invoices." } \\
\text { (Energy) }\end{array}$ \\
\hline $\begin{array}{l}\text { Coordination and control: controlling } \\
\text { spend and the sourcing and buying processes } \\
\text { within the organisation, and coordinating for } \\
\text { synergies across organisational entities (Srai } \\
\text { and Lorentz, 2019) }\end{array}$ & $\begin{array}{l}\text { e.g. "And this reduction of maverick buying, I would have wanted this } \\
\text { kind of application with which we would have started using catalogues } \\
\text { like buying from the Internet and online stores." (Food);"... and we } \\
\text { have to get it visible for the entire organisation so that we can get the } \\
\text { benefits. It does not make sense to have great contracts in the archive if } \\
\text { our people do not use them." (Chemicals) }\end{array}$ \\
\hline $\begin{array}{l}\text { Process improvement: ascertaining the } \\
\text { achievement and maintenance of } \\
\text { competitiveness of procurement function by } \\
\text { the means of resources, routines and } \\
\text { capabilities (Srai and Lorentz, 2019) }\end{array}$ & $\begin{array}{l}\text { e.g. "...no mistakes, speed, and that the outcome does not depend on } \\
\text { whether people can be bothered, or how meticulous they are, and that } \\
\text { we have the right information, and that contracts are managed and } \\
\text { accessible." (Logistics); "In practice this means all our operative } \\
\text { activities, how buying processes and tools can be made accessible and } \\
\text { easy to use for the entire organisation." (Tele) }\end{array}$ \\
\hline $\begin{array}{l}\text { Strategic alignment: alignment of company } \\
\text { and internal customer requirements with } \\
\text { external resources across items } \\
\text { and categories of spend (Srai and Lorentz, } \\
\text { 2019) }\end{array}$ & $\begin{array}{l}\text { e.g. "...we are in cost savings mode here in this company, and we have } \\
\text { to take out every bit that we can, and this has helped us achieve that." } \\
\text { (Logistics);"...me we placed the customer in the centre. In this } \\
\text { procurement organisation almost one fourth or fifth does customer } \\
\text { service work, or in other words we go through sourcing plans and we } \\
\text { do procurement road maps and so forth." (Public) }\end{array}$ \\
\hline $\begin{array}{l}\text { Supplier capability assessment: } \\
\text { monitoring the firm's agent-suppliers for } \\
\text { creating value. }\end{array}$ & $\begin{array}{l}\text { "... so we can kind of share experiences, and we can rank the products } \\
\text { and the suppliers, you can award stars, so we have brought in this kind } \\
\text { of features from the consumer context inside the solution." (Retail 2); } \\
\text { "... we can follow product movements in real time, but based on that } \\
\text { how the transport companies release this kind status data to us." } \\
\text { (HeavyMach) }\end{array}$ \\
\hline $\begin{array}{l}\text { Supplier relationship management: } \\
\text { managing power and influence of suppliers, } \\
\text { alignment of supplier incentives with those } \\
\text { of the buyer, and ensuring a return on } \\
\text { partnerships (Srai and Lorentz, 2019) }\end{array}$ & $\begin{array}{l}\text { "... we get these suppliers involved in early phase in our product } \\
\text { development, engaged and helping." (Instruments); "Maybe there is a } \\
\text { contract that has to be renewed, maybe some product or collaboration } \\
\text { project which we have to follow up on, and everything is in the same } \\
\text { tool. You get this kind of a 360-view on gthis supplier in this one } \\
\text { place." (HeavyMach) }\end{array}$ \\
\hline $\begin{array}{l}\text { Supply market knowledge management: } \\
\text { processing of market intelligence of price } \\
\text { and risk awareness, technology and new } \\
\text { supplier discovery (Srai and Lorentz, 2019) }\end{array}$ & $\begin{array}{l}\text { "... the city should utilise the well-functioning supply markets, and } \\
\text { there are some particular service areas, which you could quite } \\
\text { comprehensively analyse, and you could say that market do not } \\
\text { function properly and suppliers have a too dominating position. This } \\
\text { kind of problem, solving it, I do not yet know how, but we should be } \\
\text { able to see a bit further." (Public) }\end{array}$ \\
\hline
\end{tabular}




\section{Figure 1}

\section{Context variables of the procurement function}

\section{Context}

The problematic context driving procurement

digitalization, external and internal environment

- Variables from contingency theory, external and internal contingencies: complexity and dynamism (Duncan 1972; Souza and Voss 2008; Ellram et al. 2002; Bals et al. 2018)

- Variables from institutional theory. coercive, mimetic and formative pressure (DiM aggio and Powell 1983; Zsidisin et al. 2005)

- Variables from the strategic doicetheory. priorities regarding for instance savings, innovation or sustainability (Child 1992; Shook et al. 2009)

- Variables from innovation diffusion theory (Rogers 2010; Doherty et al. 2013)

\section{Response variables in the procurement function}

\begin{tabular}{|c|c|}
\hline $\begin{array}{l}\text { Interventions } \\
\text { Management practices and technologies, } \\
\text { specifically the digital applications or use of } \\
\text { technologies } \\
\text { - Categorization for e-procurement (de Boer } \\
\text { et al. 2002; Johnson et al. 2007) } \\
\text { - Typologies for group support systems } \\
\text { technologies (Zigurs and Buckland 1998); } \\
\text { - for inter-organizational systems (Kumar and } \\
\text { van Dissel. 1996) } \\
\text { - Basic information technology chracteristics } \\
\text { (Huber 1990) }\end{array}$ & $\begin{array}{l}\text { Mechanisms } \\
\text { Capability improvements triggered by the } \\
\text { interventions (Denyer et al., 2008) } \\
\text { - Capability improvement in the areas of } \\
\text { procurement value drivers for the } \\
\text { digitalization context (Srai and Lorentz } \\
\text { 2019) } \\
\text { - Procurement value drivers (Hartmann et } \\
\text { al. 2012) } \\
\text { Capability improvements related to e- } \\
\text { procurement (Ronchi et al. 2010; Smart } \\
\text { 2010; Toktaş-Palut et al. 2014) }\end{array}$ \\
\hline
\end{tabular}

\section{Figure $1 \mathrm{CIM}$-logic as a priori structure: theoretical foundations for context and response variables}


Figure 2

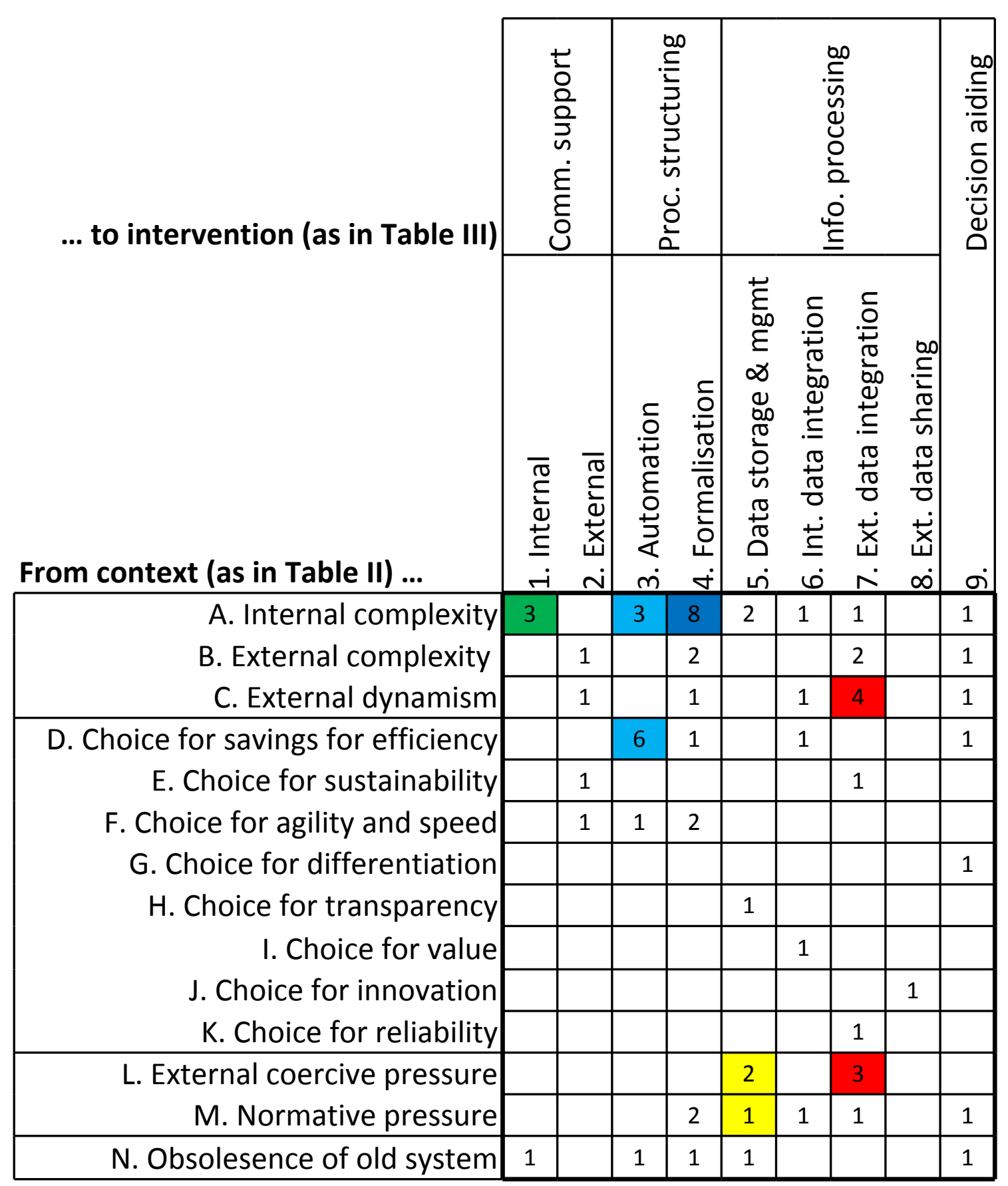

PANEL A 


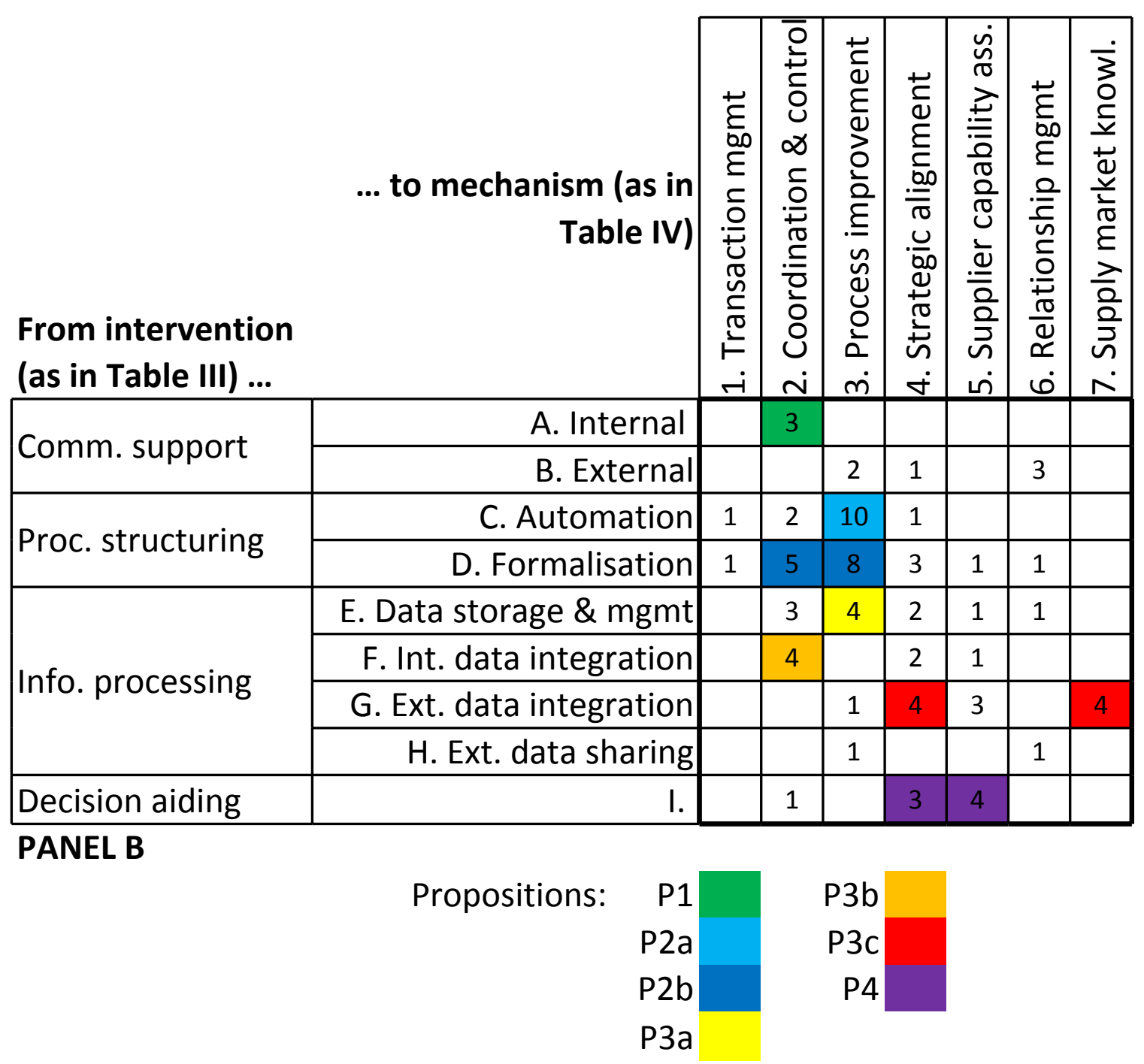


Page 41 of 47

International Journal of Operations and Production Management

2

3

4

5

6

7

8

9

10

11

12

13

14

15

16

17

18

19

20

21

22

23

24

25

26

27

28

29

30

31

32

33

34

35

36

37

38

39

40

41

42

43

44

45

46

47

48

49

50

51

52

53

54

55

56

57

58

59

60 


\section{Figure 3}

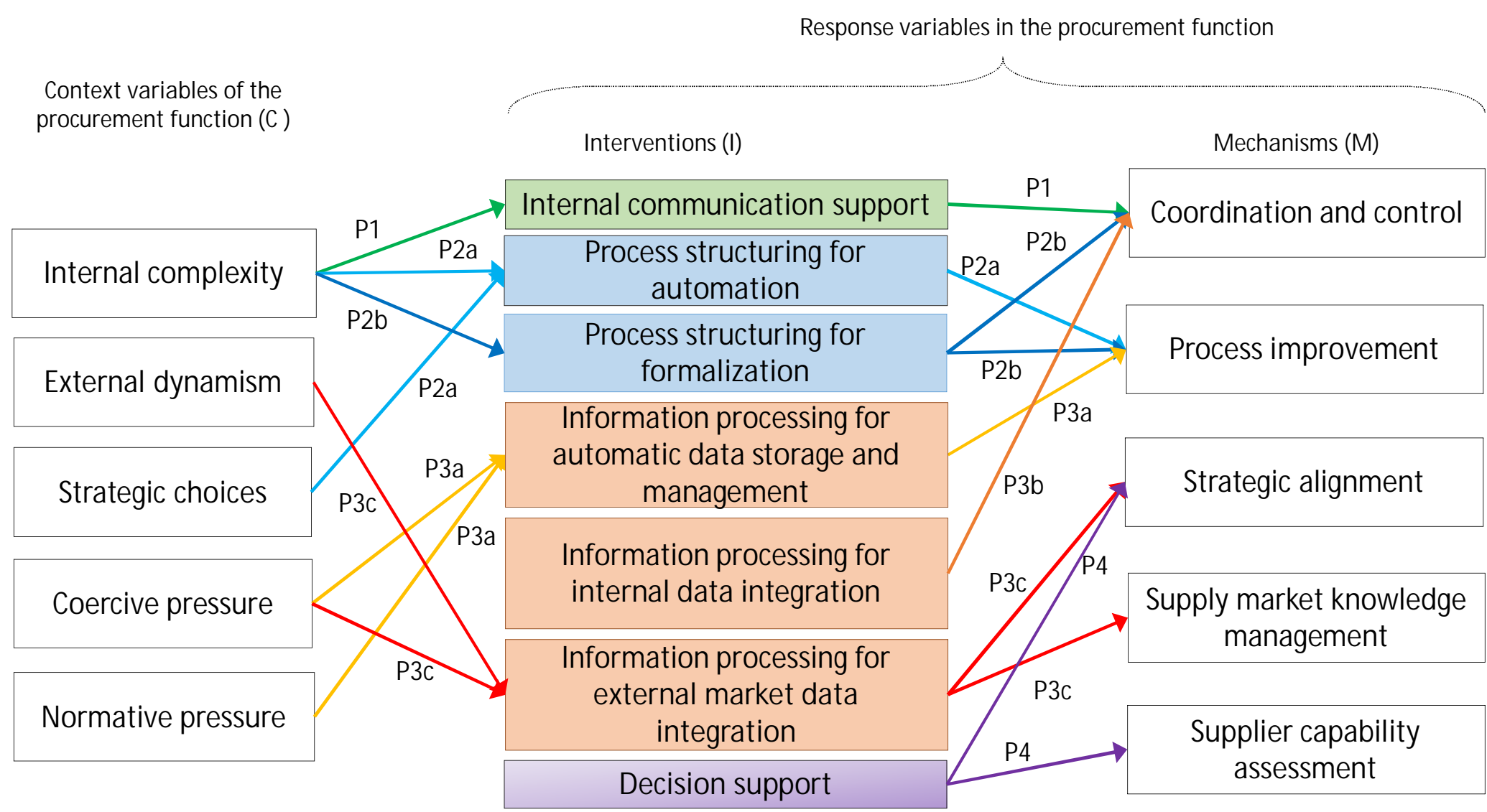

Figure 3 The linkages between context variables and response variables as stated in propositions 


\section{Response to reviewers' comments, 3rd revision}

\section{TITLE: Structuring the phenomenon of procurement digitalization: contexts, interventions and mechanisms}

Thank you for the comments and encouraging us to further refine our manuscript. Please see our response below.

\section{Associate Editor}

Comments to the Author:

The authors have done a good job taking on board the suggested advice in terms of improving the paper. There are just a few minor issues which should be considered:

Authors' response: Thank you. Happy to refine further for a more polished outcome.

In the first review you were asked to explain why you ignored certain theories. Your response articulates the reason quite well and should be included in the paper.

Authors' response: We now conclude the first paragraph of section 2.1 with the following sentence: "With focus on theories related to the interaction of context and firm, such theoretical frameworks as the resource-based view (Barney 1991), transaction cost economics (Williamson 1981), and the knowledge-based view (Kogut and Zander, 1992 Nonaka, 1994), are not selected as theoretical lenses."

12 organisations were included in the study. Some further clarification on how they were selected would be useful (third paragraph, page 8). It appears that there were three sources (two seminars, a survey (a reference to support this source should be included) and previous collaborators). What criteria were used to select them? Also, if you had 45 companies invited to two eprocurement seminars why were only three selected?

Authors' response: Thank you for this point. Indeed, we used several sources to identify potential case companies. Inclusion in the study was based on a combination of (1) maturity and resourcing of their procurement organisation (criteria: large firm, observed category management practices, procurement digitalisation on the strategic agenda), as well as (2) their willingness to commit to the study. This led to the outcome of 3 out of 45: first screening for potential (intensity sampling), and then securing of commitment. Essentially, not all organisations are willing to give sufficient level of access to informants, thus the relatively low number. We have revised the third paragraph in section 3.1 accordingly (with a more logical ordering of the sampling procedure), and a reference to the article drawing on the same survey (Lorentz et al., 2019), but different section of it, has also been included.

Figure 3, page 17 - a number of the context variables and interventions have no propositions associated with them (external complexity, data integration and decision support). This might be an issue to raise in the results and/or discussion section. 
Authors' response: We have emphasised this aspect in the section 5.3 Limitations and future work, as we now make a statement linked with the small sample size, as follows: "In this vein, it is noted that our data did not provide salient enough evidence for linking all of the observed context variables and mechanisms with interventions (e.g. external complexity), thus pointing out the need for further research."

Section 4.2 - the CI and IM elements which had a frequency of three or higher were selected for further consideration. What was the rationale for using a frequency of three? Why did you decide to combine L and M together, but not necessarily do the same for other variables? It would be useful to understand the reasoning.

Authors' response: Good point. We needed some threshold for focusing attention on the salient linkages, with richer evidence, and so we ended up selecting three, which allows focusing attention on max. 50\% of all the linkages: a good starting point for analysis. L and $M$ are both institutional pressures in nature, and thus we felt there to be enough of an affinity relationship for grouping them together, due to both relating to the need to produce external legitimacy. We have revised the text so that it includes explanation of the threshold, and is clearer on the rationale for combining $L$ and $M$.

Some of the propositions need to be tightened - P1, P2b and P4 use the term "aiming". The grammar could be better.

Authors' response: These particular propositions have been revised, with "aiming" replaced for example with "supporting". The other propositions have also been reviewed, with some changes implemented in terms of wording (e.g. "aim for" replaced by "enhance"). We have also reviewed all the propositions and implemented minor changes in order to improve structure and readability.

Minor

Page 2 - first paragraph, first sentence a little clumsy and long. Maybe split into two sentences.

Authors' response: We agree. The revised version reads as follows: "The contextual variables influencing procurement digitalisation may be divided into those of efficiency and non-efficiency orientation in nature (Sousa and Voss, 2008). Such a theoretical perspective enables a critical evaluation of the boundaries for propositions regarding universalistic adoption of various digital technology applications within procurement (cf. Busse et al., 2017), and allows for more informed practical interventions.

Page 2 - remove "if not feasible at all".

Authors' response: Done.

Page 8 - clarify the numbers in brackets "(30 and 15)".

Authors' response: This now reads "Amongst the participants (30 and 15 per seminar), ...”

Problems with arrows in Figures 1 and 2. Check document when generating pdf.

Authors' response: We have now included both Powerpoint and PDF versions of the Figures in the set of submission files in order to both provide originals for article production and preserve 
integrity of the presentation. The submission system seems to fuddle the Powerpoint versions despite our best efforts. We hope that this solution is satisfactory.

The Figures are important and so should be given more room in document.

Authors' response: The figures have been increased in size and are now as large as the margins allow, plus a bit extra. We believe that the final copy editing and article production will set the appropriate size of the Figures. We hope that this provides a satisfactory solution at this point.

In Figure 2 use larger font size for Panel A and B, in order to make them clearer.

Authors' response: The font size is now slightly bigger for Figure 2 (from 11 to 13 points in the original excel-file).

Please check all references are included.

Authors' response: Now checked, the list should be complete.

I wish you well with these minor changes.

Authors' response: Thank you! 
Figure 1

Context variables of the procurement function

\section{Context}

The problematic context driving procurement

digitalization, external and internal environment

- Variables from contingency theory; external and internal contingencies: complexity and dynamism (Duncan 1972; Souza and Voss 2008; Ellram et al. 2002; Bals et al. 2018)

- Variables from institutional theory: coercive, mimetic and formative pressure (DiMaggio and Powell 1983; Zsidisin et al. 2005)

- Variables from the strategic choice theory: priorities regarding for instance savings, innovation or sustainability (Child 1992; Shook et al. 2009)

- Variables from innovation diffusion theory (Rogers 2010; Doherty et al. 2013)

\section{Response variables in the procurement function}

\begin{tabular}{|c|c|}
\hline \multicolumn{2}{|c|}{ Response variables in the procurement function } \\
\hline $\begin{array}{l}\text { Interventions } \\
\text { Management practices and technologies, } \\
\text { specifically the digital applications or use of } \\
\text { technologies } \\
\text { - Categorization for e-procurement (de Boer } \\
\text { et al. 2002; Johnson et al. 2007) } \\
\text { - Typologies for group support systems } \\
\text { technologies (Zigurs and Buckland 1998); } \\
\text { - for inter-organizational systems (Kumar and } \\
\text { van Dissel. 1996) } \\
\text { - Basic information technology chracteristics } \\
\text { (Huber 1990) }\end{array}$ & $\begin{array}{l}\text { Mechanisms } \\
\text { Capability improvements triggered by the } \\
\text { interventions (Denyer et al., 2008) } \\
\text { - Capability improvement in the areas of } \\
\text { procurement value drivers for the } \\
\text { digitalization context (Srai and Lorentz } \\
\text { 2019) } \\
\text { - Procurement value drivers (Hartmann et } \\
\text { al. 2012) } \\
\text { Capability improvements related to e- } \\
\text { procurement (Ronchi et al. 2010; Smart } \\
\text { 2010; Toktaş-Palut et al. 2014) }\end{array}$ \\
\hline
\end{tabular}

Figure $1 \mathrm{CIM}$-logic as a priori structure: theoretical foundations for context and response variables 


\section{Figure 3}

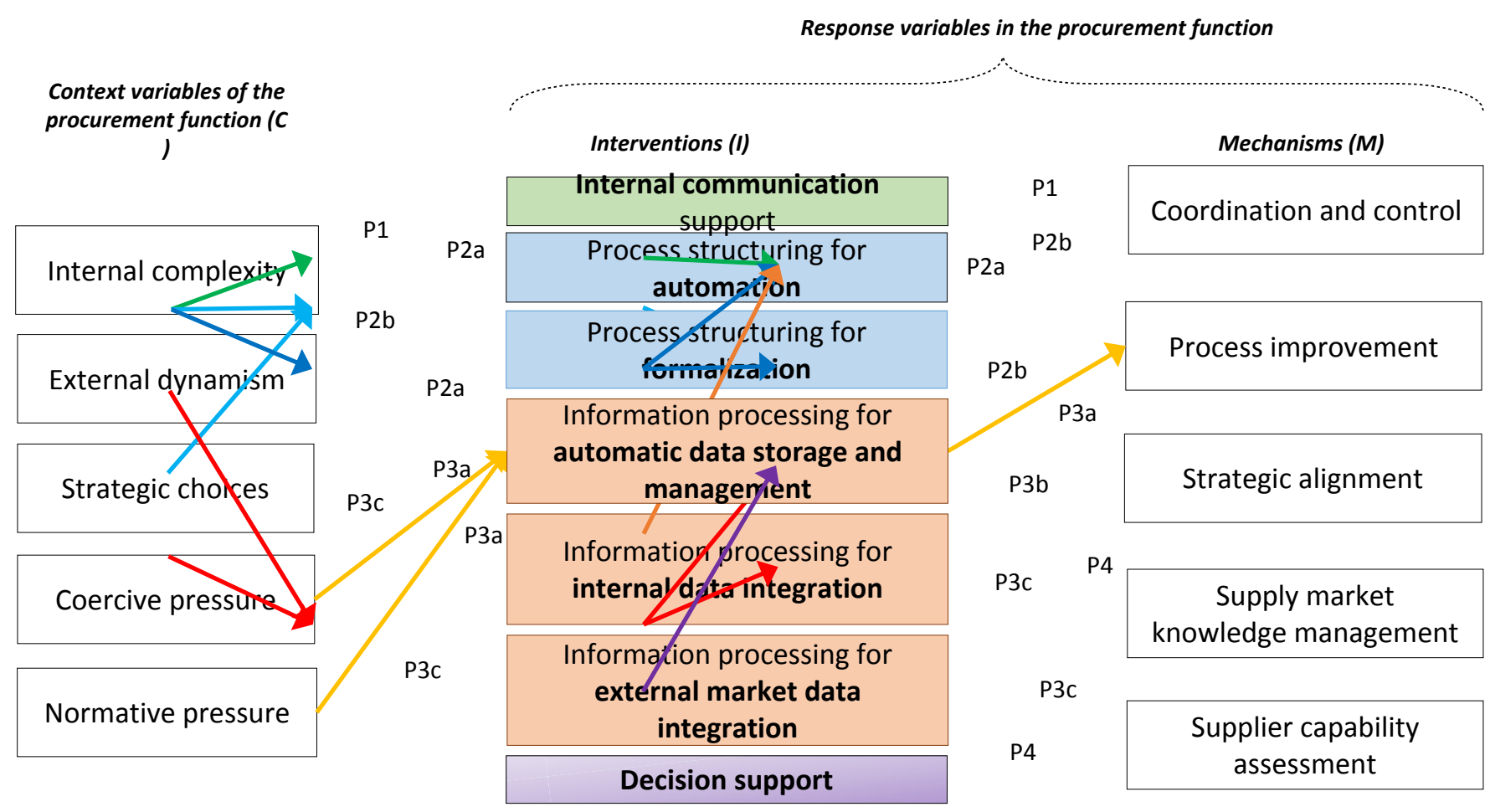

Figure 3 The linkages between context variables and response variables as stated in pl 